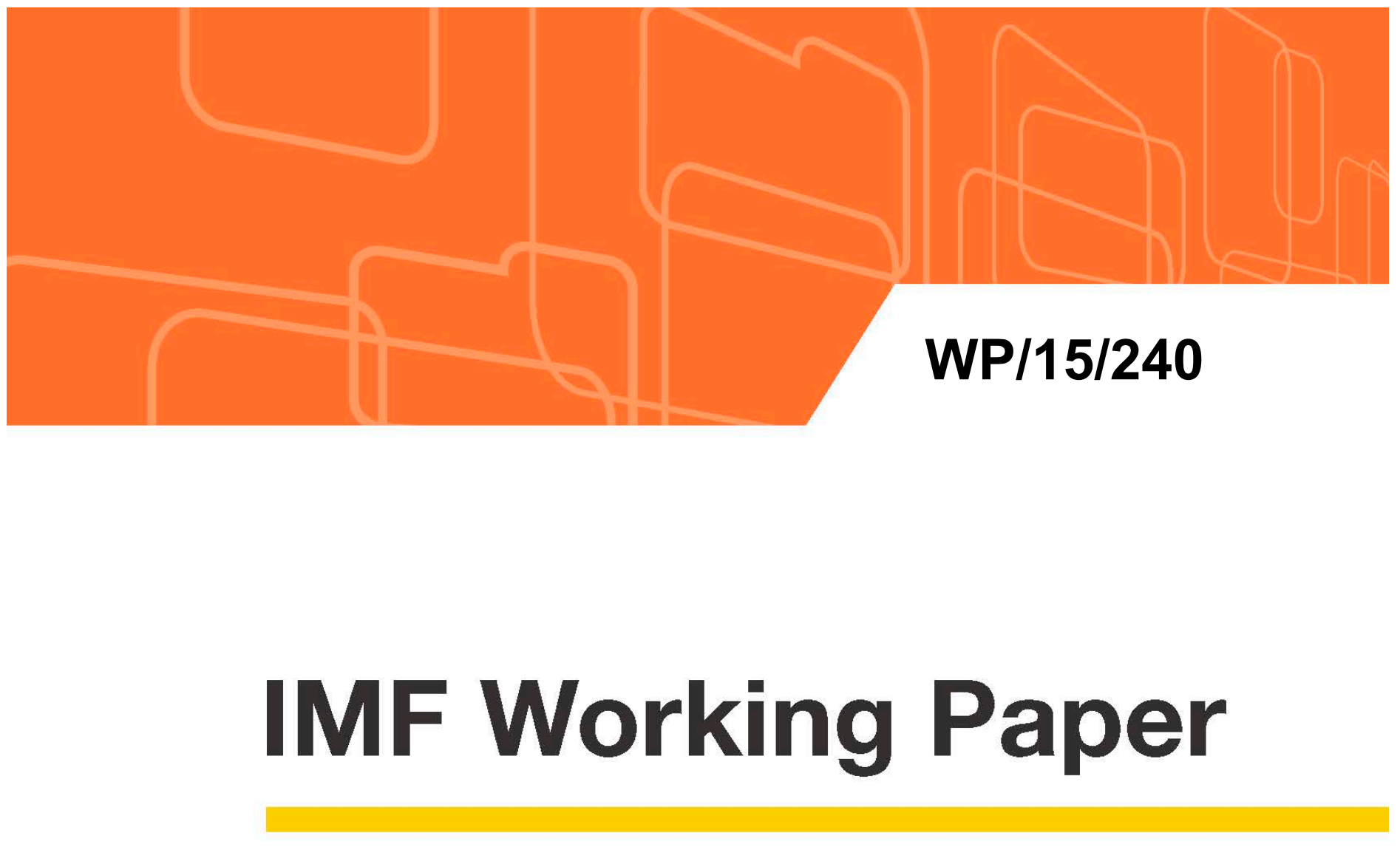

\title{
External Devaluations: Are Small States Different?
}

By Sebastian Acevedo, Aliona Cebotari, Kevin Greenidge, and Geoffrey Keim

IMF Working Papers describe research in progress by the author(s) and are published to elicit comments and to encourage debate. The views expressed in IMF Working Papers are those of the author(s) and do not necessarily represent the views of the IMF, its Executive Board, or IMF management.
I $\mathbf{N}$
$N$ T E R
R N A T $\|$ O N A L
$M O N$ E T A R Y
$F \cup \mathbb{N}$ 


\title{
IMF Working Paper
}

\author{
Western Hemisphere Department
}

External Devaluations: Are Small States Different?

\section{Prepared by Sebastian Acevedo, Aliona Cebotari, Kevin Greenidge and Geoffrey Keim ${ }^{1}$ \\ Authorized for distribution by Trevor Alleyne}

November 2015

\begin{abstract}
IMF Working Papers describe research in progress by the author(s) and are published to elicit comments and to encourage debate. The views expressed in IMF Working Papers are those of the author(s) and do not necessarily represent the views of the IMF, its Executive Board, or IMF management.
\end{abstract}

\begin{abstract}
The paper investigates whether the macroeconomic effects of external devaluations have systematically different effects in small states, which are typically more open and less diversified than larger peers. Through several analytical approaches-DSGE model, event study, and regression analysis - it finds that the effects of devaluation on growth and external balances are not significantly different between small and large states, with both groups equally likely to experience expansionary or contractionary outcomes. However, the transmission channels are different: devaluations in small states are more likely to affect demand through expenditure compression, rather than expenditure-switching channels. In particular, consumption tends to fall more sharply in small states due to adverse income effects, thereby reducing import demand. Policy conclusions point to the importance of social safety nets, complementary wage and antiinflation policies, investment-boosting reforms, and attention to potential adverse balance sheet effects to ensure positive outcomes.
\end{abstract}

JEL Classification Numbers: E65, F31, F43

Keywords: external devaluation, small states

Author's E-Mail Address: acebotari@imf.org, gkeim@,imf.org, kgreenidge@,imf.org, sacevedomejia@imf.org

\footnotetext{
${ }^{1}$ We would like to thank Derek Anderson, Mico Mrcaic, and Steven Snudden for their sizable earlier contributions to the paper.
} 


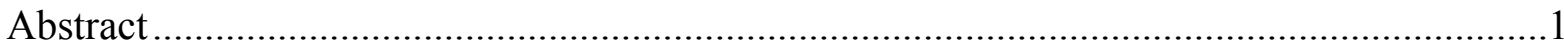

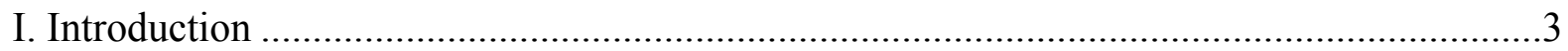

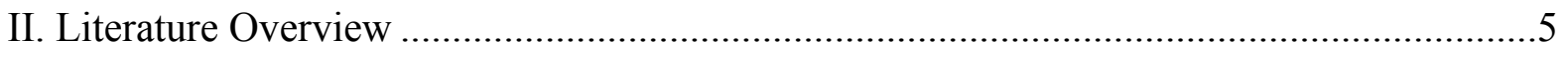

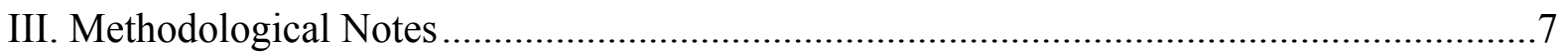

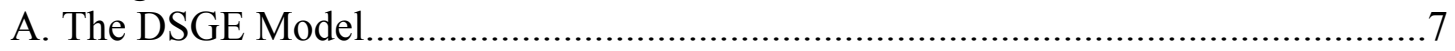

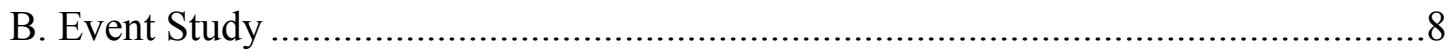

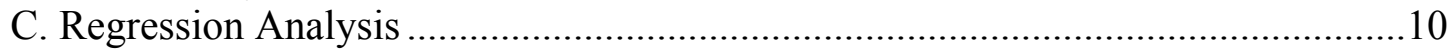

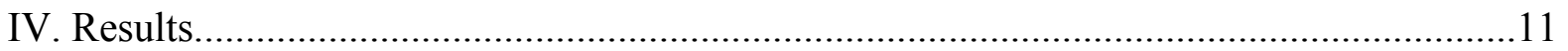

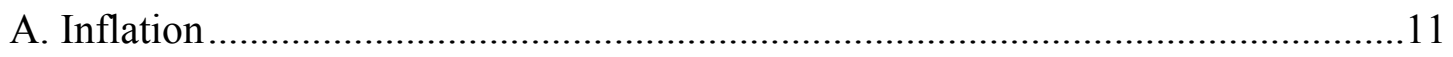

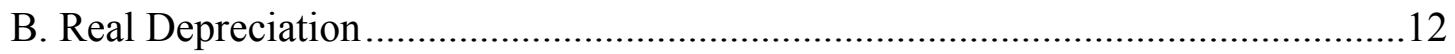

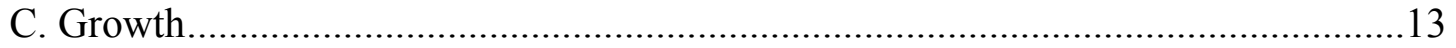

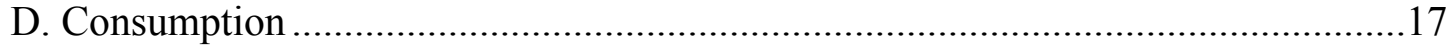

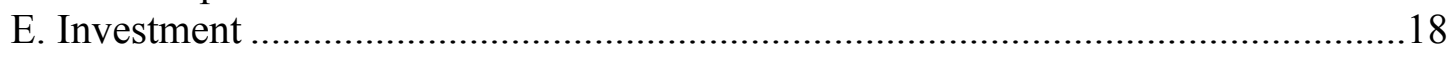

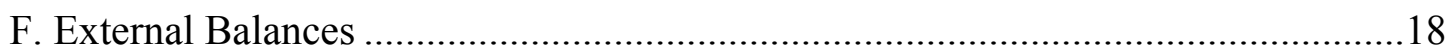

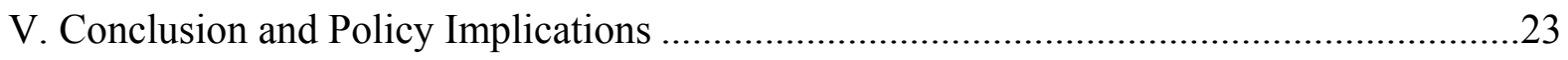

\section{TABLES}

1. Potential Channels of Contractionary Effects Identified in the Literature ......................... 7

2. Devaluation Events ..............................................................................................

3. Explanatory Variables Used in Regression Analysis................................................... 10

\section{FIGURE}

1. Event Study: Growth Outcomes in Large Devaluation Episodes ....................................15

\section{BOXES}

1. Exchange Rate Regimes in Small States .....................................................................5

2. Case Studies: Devaluations in Seychelles and Trinidad and Tobago ...............................21
AnNeXes
I. Calibration Parameters of the GIMF Model.
II. Econometric Results

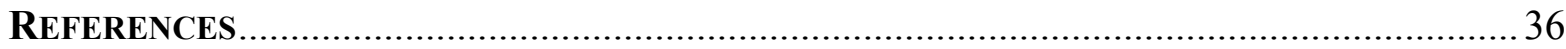




\section{INTRODUCTION}

1. The role of exchange rates in small states has come under increased debate with the weakening of their economic performance, especially after the 2008-09 global downturn. Many small states have lagged behind their peers during the past decade (IMF 2013), in part reflecting long-standing competitiveness challenges. The recent downturn has imposed an additional cost on output given the prevalence of inflexible exchange rate arrangements and recent appreciation of the U.S. dollar (Box 1). Attempts to shore up the economies with the only tool available in many countries - fiscal policies - has quickly exhausted the policy space in small states at a time when the economies remain weak and not well placed for a strong growth recovery. This has turned the focus of many policy debates back to the exchange rate as a tool to address long-standing internal imbalances (high unemployment) and external imbalances (large current account deficits and external indebtedness).

2. Small countries, however, have repeatedly voiced reservations about the efficacy of the exchange rate as a policy tool, as they see the contractionary effects of devaluations much more likely to dominate in their case. The argument is that-because small states import a large share of their consumption basket-nominal devaluations of domestic currency would lead to larger price increases which would erode the real gains in the exchange rate, failing to sufficiently improve the competitive position of a country. At the same time, the social and balance sheet costs of higher prices and the perceived loss of a strong price and macrostability anchor is seen as too high relative to the expected gains in competitiveness. As a result, many small states have opted for internal devaluations as an adjustment tool, albeit not less painful (notably Barbados in 1991, Latvia in 2009).

3. This paper aims to take a systematic look at the potential impact of large exchange rate devaluations in small states. ${ }^{2}$ The objective is to explore whether devaluations have systematically different effects in small states compared to large ones, in other words whether small states are less likely to have expansionary devaluations. The extensive literature on the effects of currency depreciations explores various transmission channels, which have both expansionary and contractionary effects on the economy, with the overall effect generally indeterminate and dependent on the characteristics of the economy. While a number of papers discuss exchange rate issues in small states, we are not aware of papers that assess the effects of external devaluations in small states and whether these are indeed different relative to large states. This paper aims to fill this gap.

\footnotetext{
${ }^{2}$ For the purposes of this paper, small states refer to countries with population of less than 2.5 million people. This group is larger than the subset of "small developing states" traditionally used in IMF publications, which refers to countries with populations of less than 1.5 million, and excludes advanced market economies and certain high-income fuel-exporters. The definition used in this paper allows the incorporation of additional observations in the empirical studies and a more precise assessment of the role "smallness" may play in affecting macroeconomic performance following devaluations.
} 
4. We study the macroeconomic effects of external devaluations in small and larger states using three methodologies:

- First, we examine the macroeconomic effects of devaluations in small states in the context of a dynamic stochastic general equilibrium (DSGE) model. This allows us to explore the interactions of the multiple channels through which devaluations can affect the real economy and their relative importance, so as to tease out the likely net effects of these channels in small-as opposed to larger-states.

- We then examine the empirical evidence from large-scale external devaluation events since the 1980s in small and large states. We identify the average stand-alone behavior of a number of macroeconomic variables (including output, consumption, investment, inflation, external current accounts and fiscal accounts) around these devaluations, and compare their behavior in small states relative to the larger countries to determine whether there are any systematic differences.

- Finally, we use various regression methods to control for policies and other factors that accompany devaluations, in order to isolate the impact of the devaluation on the macroeconomic variables, which we could not do in the event study.

5. We find that the effects of a devaluation on growth are similar for both small and larger economies: on average, an initial slowdown in growth is followed by a pickup over the medium term. The distribution of outcomes is also similar, with about half of the devaluations followed by a contraction and about half by an expansion in output. However, the channels through which devaluation affects macroeconomic outcomes differ between small and large states. Devaluation in small states is more likely to affect demand by compressing expenditure, rather than through expenditure-switching channels. In particular, consumption may be relatively harder hit in small states due to adverse income and distribution effects, combined with limited scope for import substitution or a rapid scaling up of exports due to size-related constraints. Likewise, the investment response, while ultimately strongly positive in all countries, takes longer to manifest itself in small states. The improvement in the external current account may be initially stronger in small states, but in large part it is also due to import compression. Ultimately, whether the devaluation is contractionary or expansionary overall does not appear to be related to country size but to other factors at play. Thus, devaluations can result in stronger growth in small states and improve the external position, especially if supportive policies are in place.

6. The paper is structured as follows: Section II provides a short review of the literature and the identified channels through which devaluations affect the economy; Section III discusses the three methodologies used (structural model simulation, event study and regression analysis); Section IV describes the results across all three methodologies; and Section $V$ draws conclusions and policy implications. 


\section{Box 1. Exchange Rate Regimes in Small States}

Three-quarters of small developing countries maintain fixed exchange rate regimes. About 20 percent of the small states use the most rigid arrangement, dollarization, in which another country's currency serves as legal tender, and exchange rate changes are impossible. Currency board regimes are adopted by another 20 percent of the small states and 37 percent of small states have pegs. Under both of these regimes, devaluations are uncommon but possible, and are due either to policy decisions or insufficient reserves to defend the peg through foreign exchange market intervention. For many of the 19 small states adopting currency board arrangements and pegged exchange rates, exchange rate changes have been uncommon: 14 of them have experienced flat exchange rates for more than a decade.

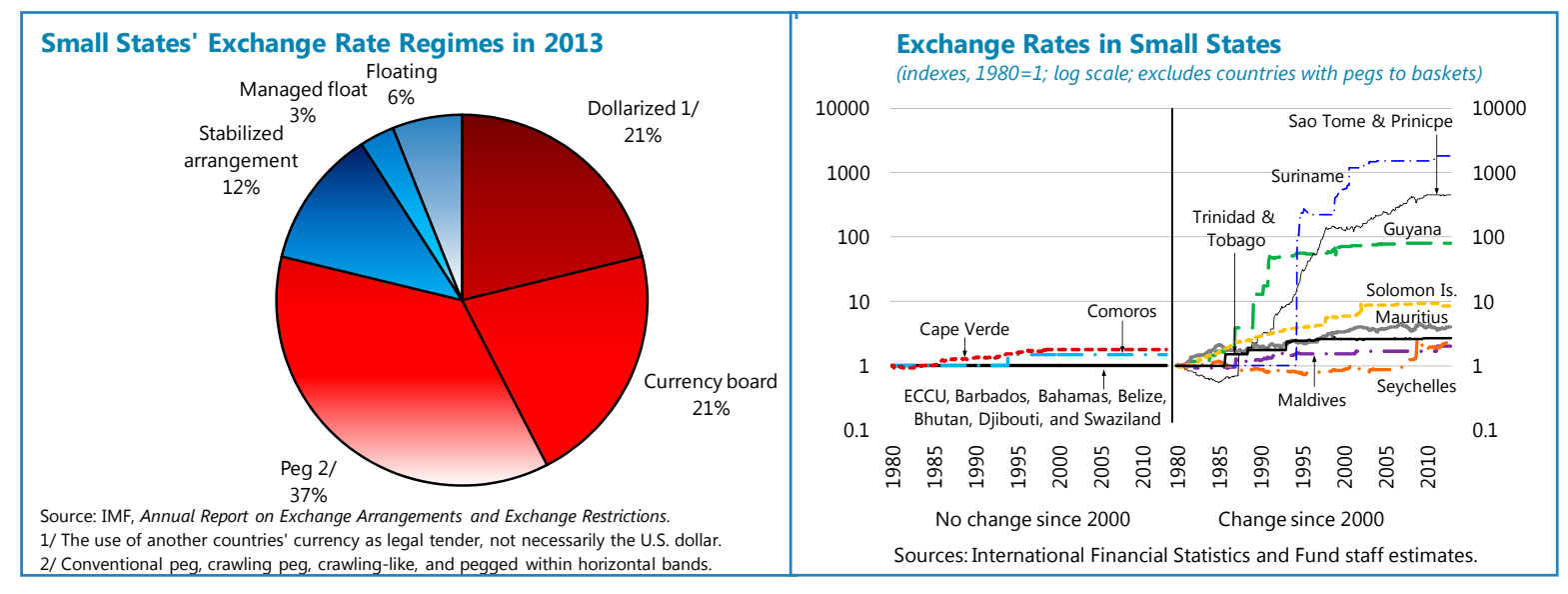

\section{Literature OVERVIEW}

7. The theoretical literature on the effects of currency depreciations is extensive and suggests that the overall effect can be indeterminate. The early literature generally focused on the positive effects for growth and current account balances that stem from the MundellFleming framework. These include expenditure-switching channels, in which the higher relative price of tradables following depreciations (i) encourages expansion of the export tradable sector by increasing its profitability and (ii) discourages imports as consumption switches towards now cheaper domestically produced substitutes. However, other papers (Table 1) have highlighted a myriad of contractionary effects such as:

\section{Negative income and distribution effects}

- Valuation effects. When devaluation occurs along with a trade deficit, the valuation effect on the initial quantities of imports and exports will reduce national income (in local currency).

\section{- Low import and export price elasticities. ${ }^{3}$ If short-term price elasticities of imports}

\footnotetext{
${ }^{3}$ In the case of imports, low elasticities could stem from inability to reduce the purchased quantities immediately following the relative price increase (if locked in by contracts) or even in the longer term (if small scale hinders availability of domestic substitutes). In the case of exports, they may also fail to respond strongly to an increase in the relative price of tradables if faced with limited diversification or growth opportunities due to scale or availability of skills.
} 
and exports are low, then devaluation could reduce net exports, worsening both external balances and growth in the short term (the J-curve effect). Even in the long run, the net effect on the trade balance would depend on the long-run demand elasticities of real imports and exports to the real effective exchange rate: if the sum of the absolute values of these elasticities exceeds unity, then depreciations would improve trade balances (the Marshall-Lerner condition).

- Distribution effects. As the profitability of the export sector increases, income is redistributed from labor towards owners of exporting firms. As the latter likely have a lower propensity to consume, overall consumption and income in the economy would decline.

- Income effects at consumer and firm level. For consumers, a fall in real wages following the post-devaluation inflation spike would reduce income and consumption, especially if they are liquidity-constrained. For firms, higher imported input costs would compress earnings and investment, especially if import and export quantities adjust sluggishly to the price increase.

- Increase in tax burden. Devaluation would raise ad valorem taxes on international trade in local currency. If overall price levels rise less than import prices, real tax burdens will increase.

\section{Negative wealth/balance sheet effects}

- The burden of servicing net foreign currency debt by households, firms, or sovereigns would increase automatically following depreciations, and risk premia could also rise, harming profitability and investment, as well as credit quality and financial stability.

8. Given the vast array of potential positive and negative effects, the overall outcome is indeterminate and depends on the structure of the economy and the decision-making parameters of its agents. Lizondo and Montiel (1989) provide an extensive discussion and Larrain and Sachs (1986) have a comprehensive overview of the earlier literature.

9. The empirical evidence on the short-term effects of the devaluations is equally inconclusive. In the context of event studies in developing countries, Cooper (1971) found devaluations to be generally contractionary over 1953-66, while Krueger (1978) found recessions in just 3 of 22 events. In a study of 195 currency crises over 1970-98, Gupta, Mishra and Sahay (2003) found 60 percent of events to have been contractionary. In econometric studies, a variety of estimation techniques have been used (e.g. Edwards (1986), Kamin and Klau (1997)) to typically find short-term contractionary effects that are subsequently reversed, with no long run impact. Magendzo (2002) adopted a matching estimators approach to avoid selection bias, finding the negative upfront effect vanished. 


\begin{tabular}{|c|c|c|c|c|c|c|c|c|c|c|}
\hline & $\begin{array}{c}\text { Lizondo } \\
\text { and } \\
\text { Montiel } \\
1989\end{array}$ & $\begin{array}{c}\text { Krugman } \\
1999\end{array}$ & $\begin{array}{c}\text { Mishkin } \\
1999\end{array}$ & $\begin{array}{c}\text { Edw ards } \\
1989\end{array}$ & $\begin{array}{c}\text { Gylfson } \\
\text { and } \\
\text { Risager } \\
1984\end{array}$ & $\begin{array}{c}\text { Gylfson } \\
\text { and } \\
\text { Schmid } \\
1983\end{array}$ & $\begin{array}{c}\text { Krugman } \\
\text { and Taylor } \\
1978\end{array}$ & $\begin{array}{c}\text { Cooper } \\
1971\end{array}$ & $\begin{array}{c}\text { Diaz- } \\
\text { Alejandro } \\
1963\end{array}$ & $\begin{array}{c}\text { Hershman } \\
1949\end{array}$ \\
\hline Low elasticities (failure of Marshall-Learner condition) & & & & & & & & $x$ & & $x$ \\
\hline Initial trade deficit & & & & & & & $\mathrm{x}$ & & & \\
\hline Taxes on international trade & $\mathrm{x}$ & & & & & & $x$ & & & \\
\hline Distribution to agents $w$ ith low MPCs & $\mathrm{x}$ & & & & & & $x$ & $\mathrm{x}$ & $\mathrm{x}$ & \\
\hline Negative real income effects & $\mathrm{x}$ & & & & & & & & & \\
\hline Costly imported imputs & $\mathrm{x}$ & & & $x$ & & $x$ & & & & \\
\hline Wealth and balance sheet effects & $x$ & $x$ & $x$ & $x$ & $x$ & $x$ & & & & \\
\hline Financial instability/risk premium & & $x$ & $x$ & & & & & & & \\
\hline
\end{tabular}

\section{Methodological Notes}

This section provides a methodological overview of the three approaches used: simulations with the DSGE model, event study, and regression analysis.

\section{A. The DSGE Model}

10. Model. To examine the differential effects of devaluations on small and larger states, we use the three-country version of the IMF's Global Integrated Fiscal and Monetary (GIMF) model, described in detail in Kumhof and others (2010). The model is a multi-region DSGE model, with optimizing behavior by households and corporates, non-neutral fiscal policy due to distortionary taxes, presence of liquidity constrained households, finite planning horizons of overlapping generations of households and other features, and monetary policy rules. We simulate the annual three-region version of the model, with the regions including: (i) the small/larger country undertaking a devaluation; (ii) the U.S.; and (iii) the rest of the world.

11. Calibration. The parameters of the model are calibrated to reflect the structure of small and larger economies (each calibration is described in more detail in Annex I). In particular, to distinguish the small countries from larger ones, we calibrate the small country as a more open economy, with a higher dependence on imports, smaller nominal rigidities (lower price adjustment costs reflecting a high degree of openness), higher real rigidities (higher quantity adjustment costs in line with narrow production base, lack of domestically produced substitutes, and limited availability of skills), and high external habit persistence. Both small and larger countries are modeled as having a peg to the U.S. dollar to facilitate comparison and tease out the differential effect of a devaluation that stems purely from the structure of the economy.

12. Simulated shock. We simulate the effects of a onetime 1 percent nominal devaluation with respect to the U.S. dollar, combined with a 0.1 percentage points increase in the sovereign risk of both small and medium countries. The size of the shock is small to allow the model to converge to a new steady state, but is sufficient to determine the relative responses of small vs. large states. The increase in sovereign risk is meant to compensate for 
the absence of foreign currency debt in the model and the associated deterioration in the sovereign's balance sheet following a devaluation. ${ }^{4}$

\section{B. Event Study}

13. The event study looks at the experience of countries with significant depreciations of their exchange rates over the last 30 years, to glean stylized facts about the behavior of macro-variables after the event. To identify the large, discrete and one-off devaluation events, we apply similar selection criteria used in Milesi-Ferretti and Razin (1998), with some additional restrictions. In particular: (i) the bilateral exchange rate had to fall by at least 20 percent (December/December); (ii) the previous year's depreciation rate could not exceed 12 percent; (iii) the rate of depreciation rose 10 percentage points from the previous year; and (iv) an event that met these criteria did not occur in the previous three years. These criteria rule out cases where there were multiple consecutive years of sharp depreciation reflecting excessively high inflation, for example. We also added a few additional restrictions to the sample to exclude events that were also not relevant for our study:

- The nominal effective exchange rate two years after the devaluation had to remain below the levels observed in the two years prior to devaluation to help eliminate temporary large commodity-price induced fluctuations in exchange rates. ${ }^{5}$

- We also exclude cases where countries with pegs to currencies other than the U.S. dollar experienced a devaluation against the U.S. dollar, but not against the peg currency. Since most countries choose to peg to the currency of a country with whom they maintain large trade links, the nominal effective exchange rate (NEER) would be expected to change little in these events. For this reason, events where the NEER depreciation, measured from one year before to one year after the devaluation, was less than 10 percent have been dropped from the sample. ${ }^{6}$ Additionally, the Common Monetary Area countries (Swaziland, Namibia, and Lesotho) and Botswana have also been excluded to preclude movements in the South African Rand from being detected as devaluations.

- Events that coincided with armed conflicts as identified by the Correlates of War dataset have been excluded to avoid distortions from security events that affect output and exchange rates.

\footnotetext{
${ }^{4}$ In many small states, a large share of the public debt is denominated in foreign currency. The valuation effect of an exchange rate depreciation would lead to an increase in the debt-to-GDP ratio, and an associated increase in sovereign risk and interest rates. Policy uncertainty following devaluations could also lead to a higher risk premium, given the traditional anchoring of monetary stability in fixed parities.

${ }^{5}$ An example of this case would be Norway's exchange rate behavior around 2008, when the bilateral exchange rate depreciated by 23 percent, following an appreciation the year before. Clearly, a large and discrete depreciation happened; however, it was largely reversed the following year, and after two years, the NEER was back to pre-event levels.

${ }^{6}$ This condition prevents the sharp fall of Bhutan's currency against the U.S. dollar in 1991, which solely reflected India's economic crisis, from being included in the sample.
} 
- Finally, because of the large structural changes and high inflation associated with the transition economies, devaluations that occurred in these countries have not been incorporated in the sample. ${ }^{7}$

14. These selection criteria lead to a final sample of 78 devaluation events, during which the bilateral U.S. dollar exchange rate depreciated by about $381 / 2$ percent on average for both the larger and smaller countries (Table 2, chart). ${ }^{8}$ The events are diverse in terms of the time that they occurred, with the 1980s and 2000s each comprising about one-quarter of the sample. About half of the events happened in the 1990s reflecting major crises, including the 1997 Asian crisis countries of Korea, Malaysia, the Philippines, and Thailand, as well as the 1994 CFA-franc devaluation, which included 15 African countries (including the Comoros). In the Western Hemisphere, cases include the well known events in Mexico in 1994, Brazil in 1999, and Argentina in 2002. The sample also includes 24 events in small countries with populations of 2.5 million people or less. These include two events each for Jamaica and Trinidad and Tobago one in the 1980s and one in the 1990s - as well as the more recent examples of the Seychelles in 2007 (see Box 2 for a case study) and Iceland in 2008.

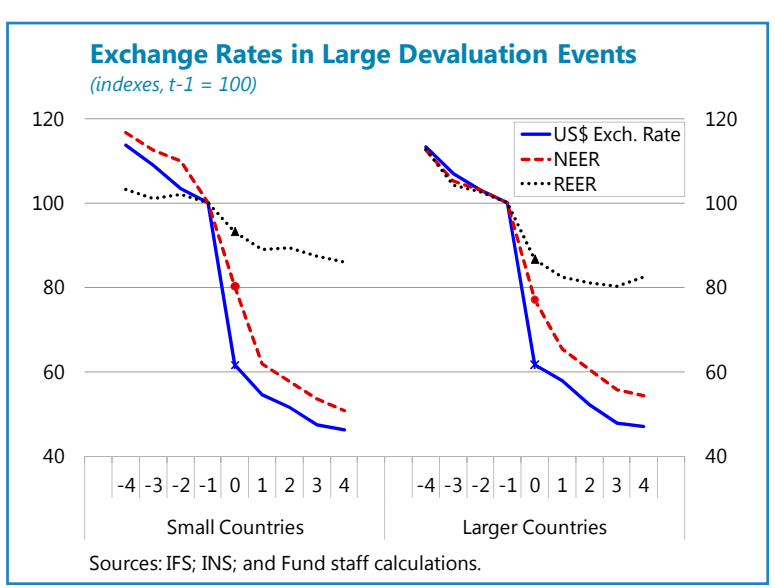

\begin{tabular}{|c|c|c|c|c|c|c|c|}
\hline Country & Year & Country & Year & Country & Year & Country & Year \\
\hline Small countries: & & Seychelles & 2007 & Sw eden & 1992 & Malaysia & 1997 \\
\hline$\overline{\text { Samoa }}$ & 1983 & Iceland & 2008 & Malawi & 1992 & Korea & 1997 \\
\hline Guinea-Bissau & 1983 & Other countries: & & Iran & 1993 & Thailand & 1997 \\
\hline Jamaica & 1983 & $\overline{\text { Sierra Leone }}$ & 1983 & Congo & 1994 & Philippines & 1997 \\
\hline Trinidad and Tobago & 1985 & Indonesia & 1983 & Central African Rep & 1994 & Zambia & 1998 \\
\hline Sao Tome and Principe & 1987 & New Zealand & 1984 & Togo & 1994 & Brazil & 1999 \\
\hline Maldives & 1987 & Venezuela & 1984 & Libya & 1994 & Haiti & 2000 \\
\hline Fiji & 1987 & China & 1984 & Benin & 1994 & Mozambique & 2000 \\
\hline Iceland & 1988 & Lao PDR & 1985 & Chad & 1994 & Paraguay & 2001 \\
\hline Sao Tome and Principe & 1991 & Dominican Republic & 1985 & Senegal & 1994 & Venezuela & 2002 \\
\hline Jamaica & 1991 & Guinea & 1986 & Mali & 1994 & Argentina & 2002 \\
\hline Mauritania & 1992 & Jordan & 1988 & Niger & 1994 & Egypt & 2003 \\
\hline Trinidad and Tobago & 1993 & Burundi & 1988 & Burkina Faso & 1994 & Guinea & 2004 \\
\hline Suriname & 1994 & Algeria & 1988 & Cameroon & 1994 & Madagascar & 2004 \\
\hline Comoros & 1994 & Zambia & 1989 & Cote d'Ivoire & 1994 & Mozambique & 2005 \\
\hline Gabon & 1994 & Honduras & 1990 & Mexico & 1994 & Ghana & 2008 \\
\hline $\mathrm{Fiji}$ & 1998 & Rw anda & 1990 & China & 1994 & Korea & 2008 \\
\hline Suriname & 1999 & Haiti & 1991 & Lao PDR & 1995 & South Africa & 2008 \\
\hline Gambia & 2000 & Nepal & 1991 & South Africa & 1996 & Turkey & 2008 \\
\hline Solomon Islands & 2002 & India & 1991 & Papua New Guinea & 1997 & Sierra Leone & 2009 \\
\hline
\end{tabular}

\footnotetext{
${ }^{7}$ Other excluded events were Equatorial Guinea, 1994, following the discovery of large oil deposits and the Democratic Republic of the Congo, 1998; Jamaica's 1991 devaluation was set upon exchange rate regime unification.
}

${ }^{8}$ Outlier Sao Tome \& Principe's 1987 devaluation was excluded to avoid skewing the averages. 


\section{Regression Analysis}

15. Devaluations do not occur in isolation - usually they are parts of a wider crisis - and are accompanied by policies that affect macroeconomic outcomes along with the devaluation. In the regression analysis, we therefore control for these other determinants to isolate the impact of the devaluation, which we could not do in the event study.

16. As in the event study, the key empirical question is whether devaluations affect macroeconomic outcomes differently in small countries than in larger ones. We approach this question by estimating the relationship between devaluations and the macroeconomic variables of interest, by employing several different regression models and by checking for the consistency of the results to verify their robustness. Data used to perform the analysis were largely sourced from World Economic Outlook, the related Global Economic Environment, or the International Financial Statistics. Depending on data availability, the sample covered 114-135 countries over the period 1980-2013, and excluded the United States and observations occurring during armed conflicts. In some cases real national accounts aggregates were limited and nominal data were deflated by the CPI.

\begin{tabular}{|c|c|c|c|c|c|c|c|c|c|c|c|c|c|c|}
\hline \multirow{2}{*}{$\begin{array}{l}\text { Dependent variable: } \\
G=\text { General model; } R=\text { Reduced model }\end{array}$} & \multicolumn{2}{|c|}{$\begin{array}{l}\text { Real } \\
\text { GDP }\end{array}$} & \multicolumn{2}{|c|}{$\begin{array}{c}\begin{array}{c}\text { Private } \\
\text { cons- } \\
\text { umption 1/ }\end{array} \\
\end{array}$} & \multicolumn{2}{|c|}{$\begin{array}{l}\text { Investm } \\
\text { ent } 1 /\end{array}$} & \multicolumn{2}{|c|}{$\begin{array}{c}\text { Real } \\
\text { exports }\end{array}$} & \multicolumn{2}{|c|}{$\begin{array}{c}\text { Real } \\
\text { imports }\end{array}$} & \multicolumn{2}{|c|}{$\begin{array}{c}\text { Current } \\
\text { account } \\
\text { balance/GDP }\end{array}$} & \multicolumn{2}{|c|}{$\begin{array}{c}\text { CPI } \\
\text { inflation } \\
\end{array}$} \\
\hline & $\bar{G}$ & $\mathrm{R}$ & $\mathrm{G}$ & $\frac{\mathrm{R}}{\mathrm{R}}$ & $\bar{G}$ & $\bar{R}$ & $\bar{G}$ & $\mathrm{R}$ & $\mathrm{G}$ & $\bar{R}$ & G & $\bar{R}$ & $\mathrm{G}$ & $\mathrm{R}$ \\
\hline \multicolumn{15}{|l|}{ Measured in changes of log levels: 21} \\
\hline Trading partners' real GDP & $\mathrm{x}$ & $x$ & & & & & $x$ & $x$ & & & & & & \\
\hline Lagged own real GDP & $x$ & $x$ & $\mathrm{x}$ & $\mathrm{x}$ & & & & & & & & & & \\
\hline Trading partners real GDP/own real GDP & & & & & & & & & & & $\mathrm{x}$ & $\mathrm{x}$ & & \\
\hline Private credit $1 /$ & $x$ & $x$ & & & $x$ & $x$ & & & & & $x$ & $x$ & & \\
\hline Official dev. dssistance & & & & & & & & & $x$ & $x$ & $x$ & $x$ & & \\
\hline Output gap & & & & & & & & & & & & & $x$ & $x$ \\
\hline Private consumption & & & & & $x$ & $x$ & & & $x$ & $x$ & & & & \\
\hline Private investment & & & & & & & & & $x$ & $x$ & $x$ & $\mathrm{x}$ & & \\
\hline Real exports & & & & & $\mathrm{x}$ & $\mathrm{x}$ & & & & & & & & \\
\hline Nominal exchange rate & & & $\mathrm{x}$ & $\mathrm{x}$ & & & $\mathrm{x}$ & $\mathrm{x}$ & $\mathrm{x}$ & $x$ & $\mathrm{x}$ & $x$ & $x$ & $\mathrm{x}$ \\
\hline Nom. exch. rate $\mathrm{x}$ small country & & & & & & & $x$ & $x$ & & & $x$ & $x$ & $x$ & $x$ \\
\hline Price differential & & & & & & & $x$ & $x$ & $x$ & $x$ & & & & \\
\hline Government expenditures & $\mathrm{x}$ & $\mathrm{x}$ & & & & & & & & & & & & \\
\hline Broad money supply growth & & & & & & & & & & & & & $x$ & $x$ \\
\hline U.S. CPI inflation & & & & & & & & & & & & & $x$ & $x$ \\
\hline \multicolumn{15}{|l|}{ Indicator variables: } \\
\hline Devaluation & $x$ & $\mathrm{x}$ & $x$ & $x$ & $x$ & $x$ & & & $x$ & $\mathrm{x}$ & & & & \\
\hline Devaluation $\mathrm{x}$ small state & $x$ & $x$ & $x$ & $x$ & $x$ & $x$ & & & $x$ & $x$ & & & & \\
\hline Banking crisis 2/ & $x$ & $x$ & $x$ & $x$ & $x$ & $x$ & $\mathrm{x}$ & $\mathrm{x}$ & $x$ & $x$ & $\mathrm{x}$ & $\mathrm{x}$ & & \\
\hline Sovereign default $2 /$ & $x$ & $x$ & $x$ & $x$ & $x$ & $x$ & $x$ & $x$ & $x$ & $x$ & $x$ & & & \\
\hline Public debt $>60 \%$ GDP & $x$ & $x$ & & & $x$ & $x$ & & & & & & & & \\
\hline Small state & & & & & & & & & & & $x$ & $x$ & & \\
\hline \multicolumn{15}{|l|}{ 1/ Deflated by CPI. } \\
\hline \multicolumn{15}{|c|}{$\begin{array}{l}\text { 2/ An "X" in the reduced model equation implies that the variable withstood the model reduction process in at least } \\
\text { one technique. In equations estimated by pooled OLS with cointegration, fixed effects with cointegration, and dynamic } \\
\text { least squares, lagged dependent variables and log levels of certain variables were included. Dynamic OLS regressions } \\
\text { included error correction terms. }\end{array}$} \\
\hline
\end{tabular}


17. Equations were estimated for the major macroeconomic variables (output, consumption, investment, exports, imports, the external current account, and inflation) and the results are shown in Annex II. Four different estimation strategies were used: static fixed effects, pooled OLS with cointegration, fixed effects with cointegration and an unrestricted error correction model/dynamic OLS, with a general-to-specific approach used for each technique. The rows of Table 3 show the explanatory variables of both the general and specific models, of which up to two lags were used. These explanatory variables include indicators of economic conditions at the time of the devaluation externally (trading partners' output, U.S. inflation), domestically (country's lagged output, output gap and dummy variables for banking crises and sovereign defaults from Laeven and Valencia (2008), which ensures that the devaluation effects are net of any crisis effects) and policy settings (government expenditures, broad money growth, dummy for large public debt levels), among others. Some specifications also include dummy variables denoting large devaluations, which conform to the same criteria as used in the event study. Interaction terms of the large devaluation dummy with a dummy variable for small states permit tests for differential impacts on small countries. Where statistically significant small country effects were found, they are shown in the charts.

\section{REsults}

In this section, we summarize the results across the three studies in terms of the likely effect of a nominal devaluation on macroeconomic outcomes. The main finding is that large devaluations do not appear to lead to different growth outcomes in small and larger states, and can boost investment and exports, but the negative effects of expenditure compression could be particularly apparent in small states.

\section{A. Inflation}

18. Following large depreciations, the short term pass-through of an exchange rate depreciation to inflation appears to be faster and stronger in small states, reflecting the higher import content of production and consumption. During past events of large depreciations, for example, inflation surged from a median of about $7 \frac{1}{2}$ percent in the year before depreciation in both small and larger countries to $16 \frac{1}{2}$ percent in small economies and $13^{1 / 2}$ percent in the larger economies. However, we found that inflation also fell faster in small states. The differences in outcomes, however, are not statistically significant after the first year, as can also be seen in the distribution of inflation changes post-depreciations.

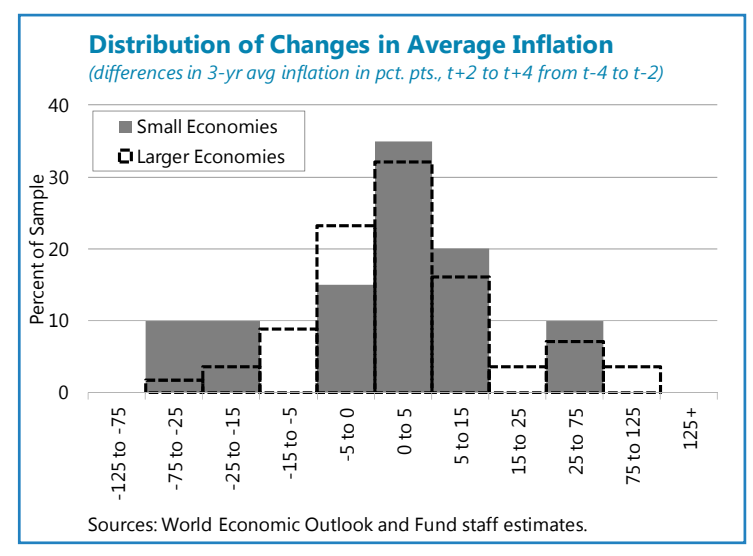




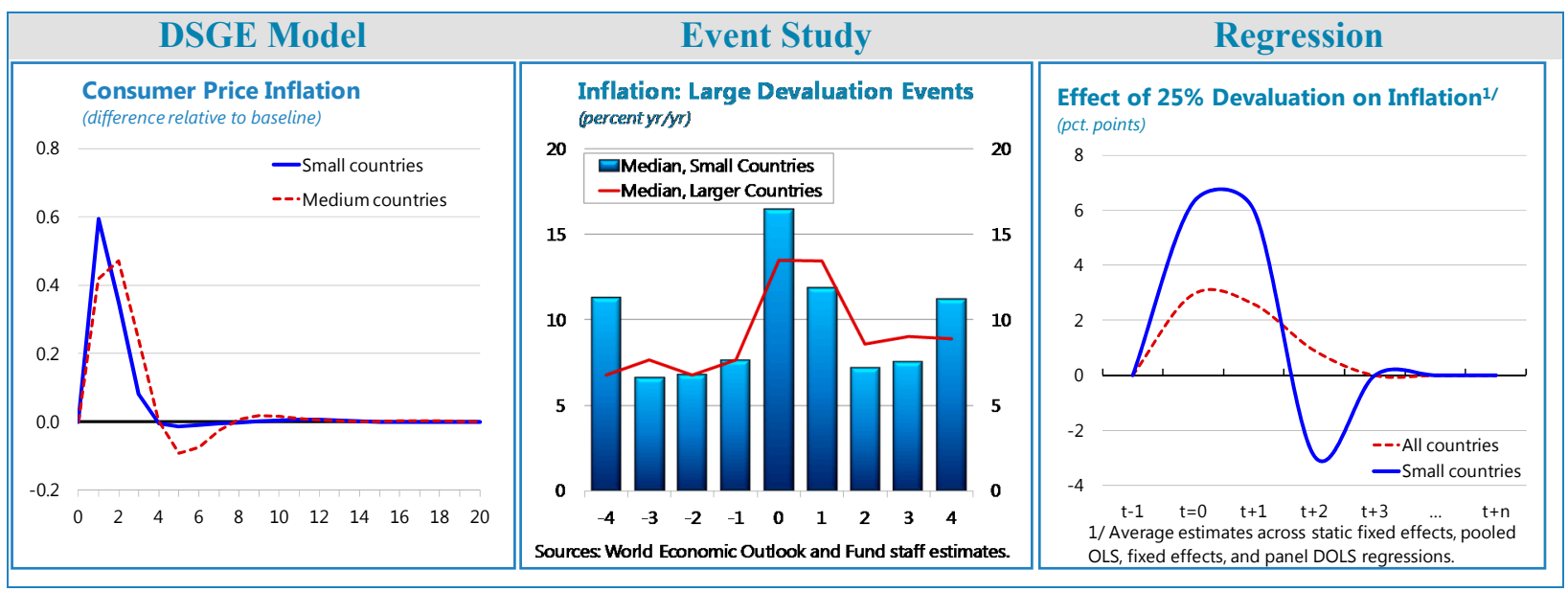

\section{B. Real Depreciation}

19. As a result of the response in inflation, the real depreciation might be smaller in small states for a given size nominal depreciation. Despite the marginally higher nominal depreciation, the real effective exchange rate (REER) was about 14 percent below predepreciation levels in small states and 18 percent lower in larger countries after four years post-depreciation.

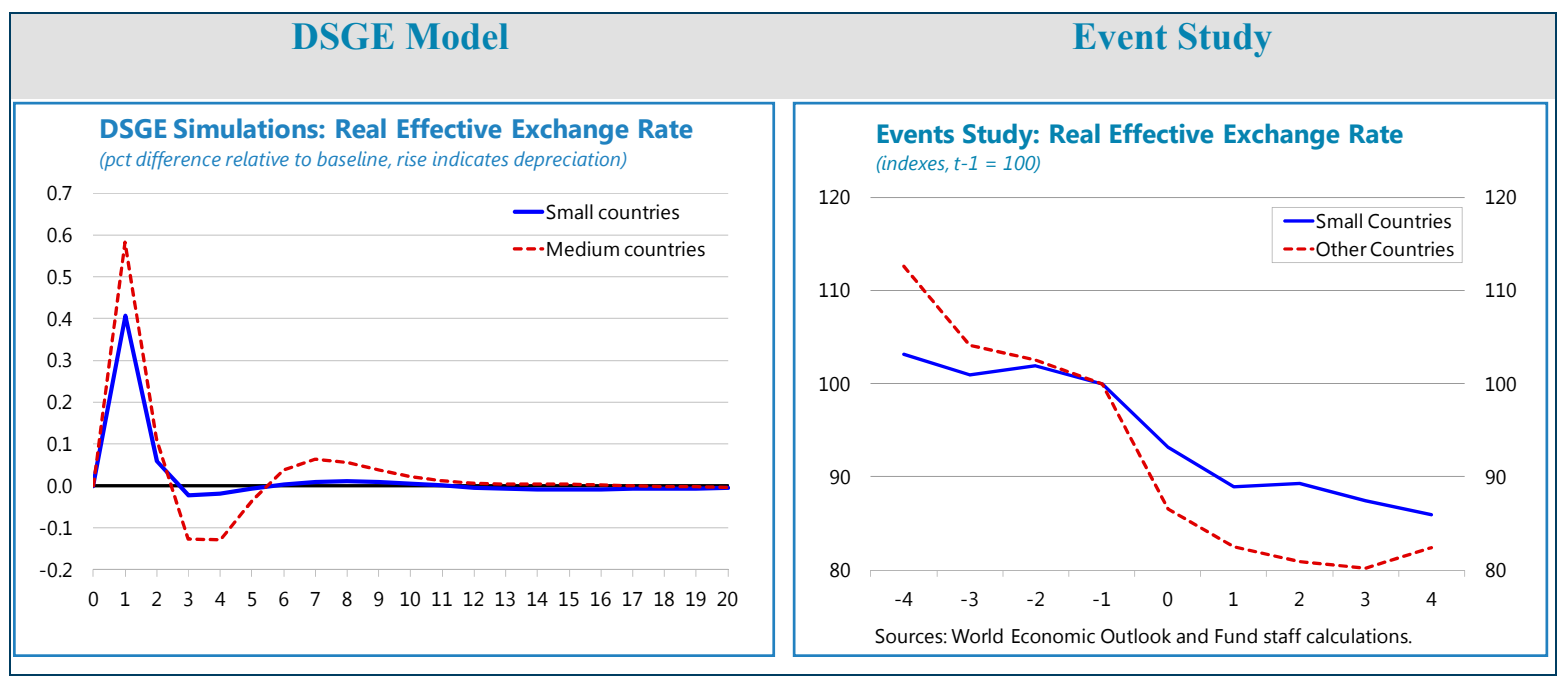

20. Given the importance of containing inflation to generate real depreciation gains, we used a probit regression to look at the factors that increase the probability of inflation being brought fast under control. ${ }^{9}$ The results suggest the importance of tight incomes policies and

\footnotetext{
${ }^{9}$ In this instance, "success" in controlling inflation refers to cases in which the average inflation rate 2-4 years after the devaluation was lower than the average inflation rate 2-4 years before the devaluation. The variables hypothesized to affect success were a dummy for small countries, changes in average world food and fuel prices, changes in U.S. inflation, changes in nominal exchange rates, the growth of real government wage expenditures and the real M2 money supply.
} 
preventing further rounds of depreciation, which could have a more persistent effect on inflation. The coefficient estimates on both wage growth and depreciation in the postdevaluation period are significant and negative in sign, implying that public sector wage increases or loose monetary policies tend to limit the probability that a country will bring inflation under control following a devaluation. The estimate on the small countries dummy was not significant, implying that they do not face an inherent disadvantage in achieving price stability in the years following a devaluation, even if the initial effects tend to be larger.

\section{Growth}

21. The empirical evidence suggests that average growth outcomes following devaluations are similar in small and larger states, with an immediate slowdown followed by a pickup over the medium term. The distribution of outcomes is also similar, and reveals a large range of outcomes, with about half of the devaluations followed by a contraction and half by an expansion in output. The results for the model simulations are somewhat different than the empirical averages but consistent with a significant range of outcomes, and highlight the possibly more contractionary effects of devaluations in small states.

\section{Empirical Studies}

22. The evidence from our empirical studies suggests that on average: (i) large depreciations may dampen growth in the short term, but boost it over the medium term, with no long-run effects, and that (ii) the results for small and large economies are similar in the two empirical studies. As we will see below, however, the transmission channels and the composition of growth between small and large states would, in fact, differ significantly.

- In the event study, growth declines immediately following devaluations both in small and large states, exacerbating the weakening trend prior to the devaluation. Growth picks up notably over the medium-term, with the pickup somewhat stronger in small states (1.3 percentage points, compared to 1.1 in larger economies, between years 2-4 prior and post devaluation), although not in a statistically significant way. ${ }^{10}$

- The distribution of outcomes is also broadly similar among the small and large states (histogram). Within the entire sample, about half

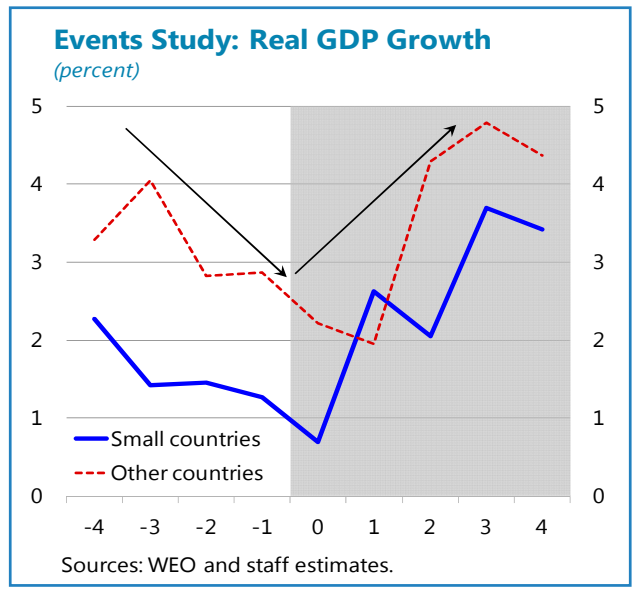
the events - 51 percent - experienced some degree of growth pickup, even if small. In the case of small states, a slight majority (13 cases, or 62 percent) experienced a pickup, while for the larger countries just under a majority (27 cases, or 47 percent). In some cases, small states experienced growth in one devaluation episode (e.g. Jamaica

\footnotetext{
${ }^{10}$ While the pick-up in growth post-devaluation is broadly similar across the two groups, average growth is lower in smaller countries both before the devaluations and after, resulting in an overall lower level of GDP if measured from the pre-devaluation year.
} 
1983, Fiji 1987, Trinidad and Tobago 1993) but not in others (Jamaica 1991, Trinidad and Tobago in 1985, Fiji 1998), suggesting that underlying country economic institutions and structures are less important than the policy or overall economic context. A non-negligible amount of devaluation events -14 percent of the small state events and 11 percent of large state events-are followed by significant slowdown in growth.

- The similar growth behavior of small and large states following devaluations is robust to further econometric analysis that controls for other factors (see Annex II for detailed results). Here, large nominal devaluations have immediate negative effect on real growth. The effects turn positive starting in the second year, and die out overtime and as such we find no significant long-run growth effects. The interaction term between devaluation and small countries dummy is not significant at any lag, suggesting the growth effects of large devaluations are not significantly different for small countries relative to the average effect for all countries in the sample. While the cumulative effect of the devaluation alone may be on average negative (chart), this does not mean there is a

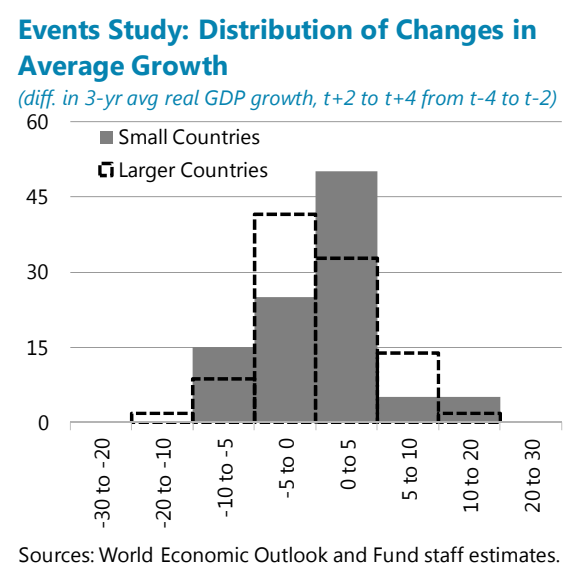

Sources: World Economic Outlook and Fund staff estimates.

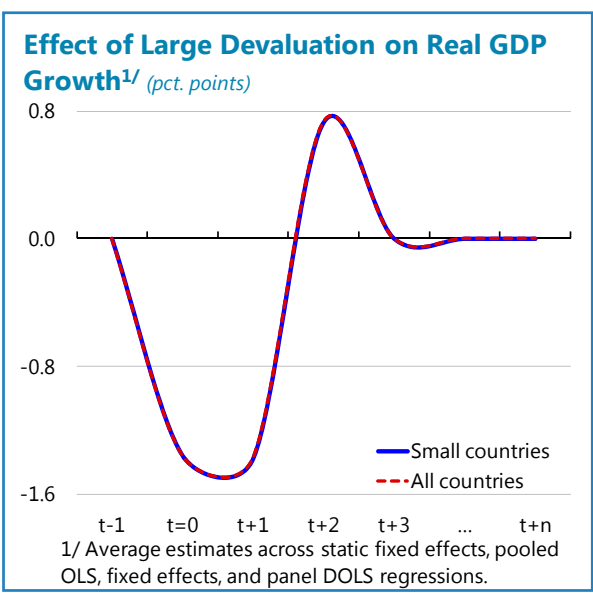
permanent loss in output. The empirical evidence suggests that other factors (supportive policies, external environment or credit conditions) offset this effect and allow a strong pick-up in growth post-devaluations.

23. What factors determine positive growth outcomes or increase the probability of growth pickups post-devaluation? Strong external demand and robust domestic credit growth post-devaluation (and by extension a financial sector that is in a position to support such growth) show a strong positive relationship with growth. From a separate probit regression, factors that affected the probability of an expansionary devaluation included growth in trading partner countries, private credit growth, and a pick-up in investment, suggesting that policies that boost confidence and promote investment can help lock in the potential gains; there was no evidence that small countries have inherently lower odds of experiencing an upturn in growth. ${ }^{11}$

\footnotetext{
${ }^{11}$ We define a growth pickup when the average three-year growth rate from years $2-4$ following the devaluation exceeds the average growth rate in years 2-4 before the devaluation. The independent variables include countryspecific factors such as a binary variable denoting small countries, the change in gross capital formation as a share of GDP, average real GDP growth of trading partners, and private credit growth. Alternate specifications included the government wage bill (in percent of GDP), other government expenditures (in percent of GDP), and the change in the real effective exchange rate as explanatory variables, although they were not statistically significant.
} 


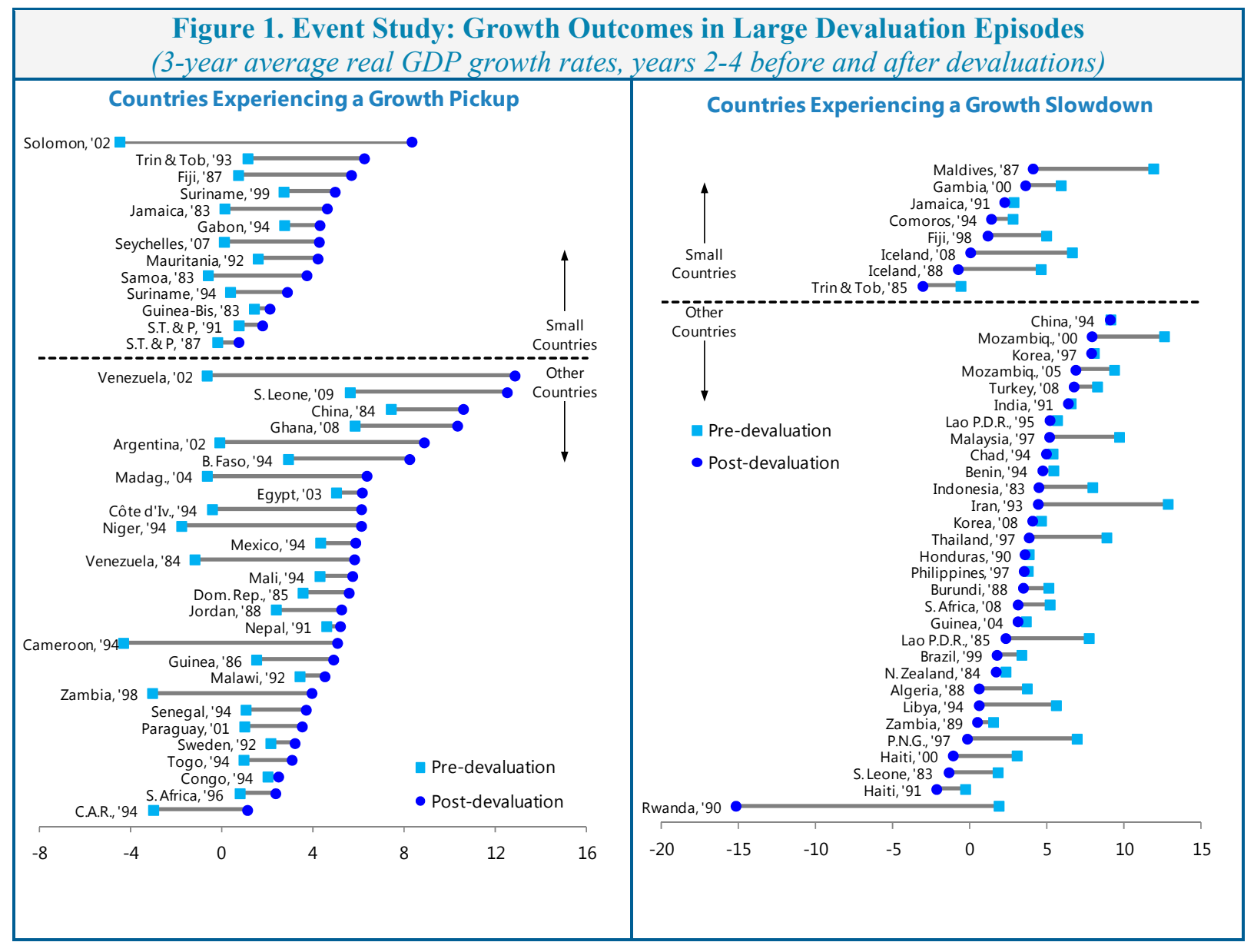

\section{Model Simulations}

24. In the DSGE simulations, real output expands in both small and large states under our calibration parameters, but the expansion is more muted in small states and fades in the long term. While the first two effects are somewhat different than the average outcomes in empirical studies, they are not inconsistent with a significant spectrum of the devaluation outcomes. In reality, the response to a devaluation will depend on a large number of factors, such as the degree of balance sheet dollarization, the response of fiscal and monetary policies, the exchange rate regime, and confidence effects.

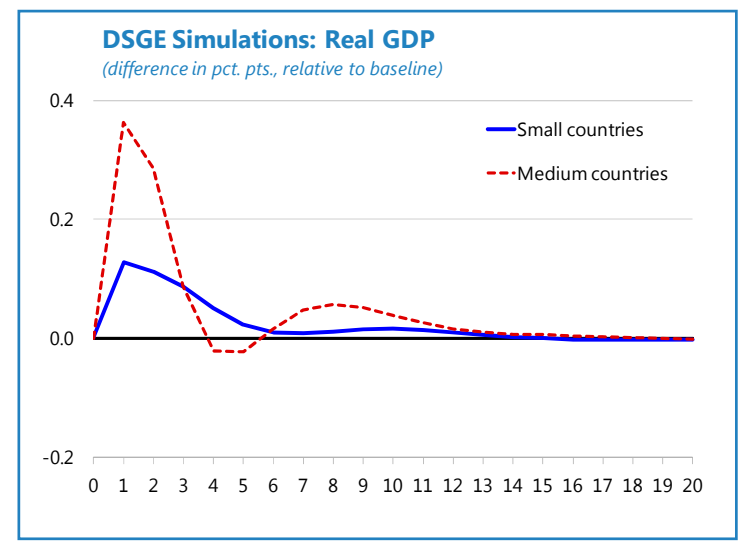

25. As an illustration of these possibilities, we performed a number of supplementary simulations on the small economy model only to show that different economic structures or different policies can be associated with different outcomes, with right policies helping to lock in the shorter-run gains from devaluation over more extended horizons. For example: 
- In small states with large foreign exchange liabilities, the loss in net worth associated with a devaluation would have strong dampening effects on financial wealth, investment and consumption, and would therefore have a more contractionary effect on the economy, even in the longer run (scenario with the higher risk premium in the embedded chart).

- A larger share of hand-to-mouth (liquidity constrained) consumers - for instance in countries with lower financial inclusionwould be associated with less expansionary outcomes as a result of the contraction in consumption experienced by these consumers following the post-devaluation fall in real incomes (discussed below).

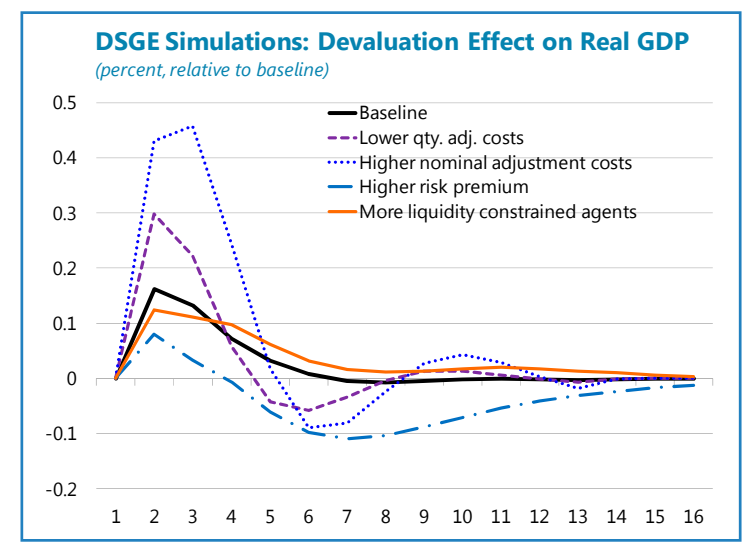

- In the case of a loss in competitiveness, the gains in output afforded by the devaluation over the medium term could be used to jumpstart growth, while buying time for other policies to be put in place to sustain it. In the baseline simulation in the embedded chart, output declines as a result of a loss in competitiveness from an increase in real wages, which leads to lower employment, investment, consumption and exports. ${ }^{12}$ This loss can be offset for 5-6 years by the output gains from a devaluation, which may not persist over the long-term. However, this mediumterm timeframe could buy sufficient time for other policies to yield results under a stronger economic environment, including structural reforms to boost competition in the labor markets, switch government spending from consumption to infrastructure, with the increased investment providing a strong longrun effect on output, external balances and wealth. ${ }^{13}$

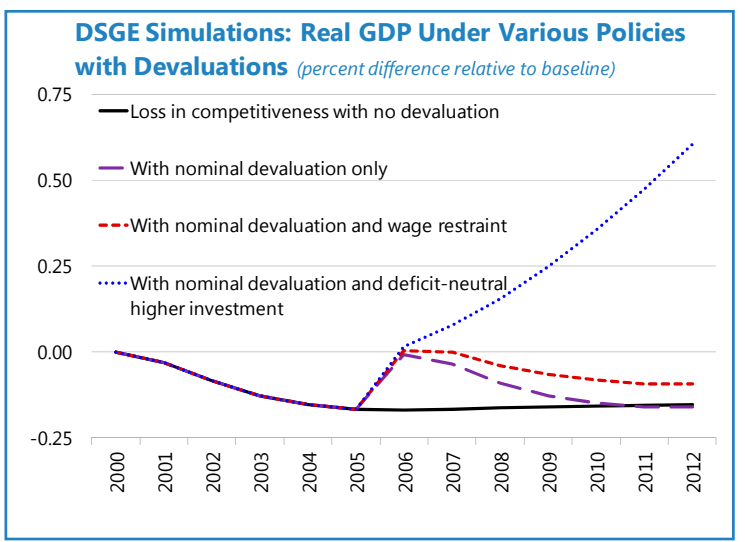

26. In model simulations, devaluations are less expansionary in small states as a result of a more subdued response of domestic demand, especially consumption, and the inability to scale up exports as fast as in larger states - all features borne out in our empirical findings that are discussed below.

\footnotetext{
12 The simulations in this bullet include: (i) a loss in competitiveness from a $1 / 2$ percentage point increase in the wage markup, which increase real wages (baseline scenario); (ii) a wage restraint simulation, which reverses 0.2 percentage points of the rise in the wage markup in the fifth year along with the devaluation shock; and (iii) replacing $1 / 2$ percent of GDP of government consumption expenditures with an equal amount of higher infrastructure spending.

${ }^{13}$ In reality, the gains from devaluation could be larger than simulations in the chart suggest (given that we can only simulate a small devaluation of 1 percent) and the gain from the structural reforms could be much slower to manifest themselves, lending further importance to the timeframe bought by the devaluation for jumpstarting growth.
} 


\section{Consumption}

27. The effect of the devaluation on consumption revealed the biggest difference between outcomes in small and large states. While in larger states consumption grows robustly with a pickup in disposable income, in smaller states consumption is weak or even falls immediately following the devaluation and remains flat into the medium term. ${ }^{14}$ These results suggest that the expenditure compression (income) effect may be quite strong in small states, and may dominate the expenditure switching effects. The results seem to support the focus of much of the literature on the contractionary income and distributional effects of a devaluation, in particular a potential fall in consumption due to a decline and reallocation of disposable income from households with a higher marginal propensity to consume towards owners of capital, with the attendant increase in investment (see below).

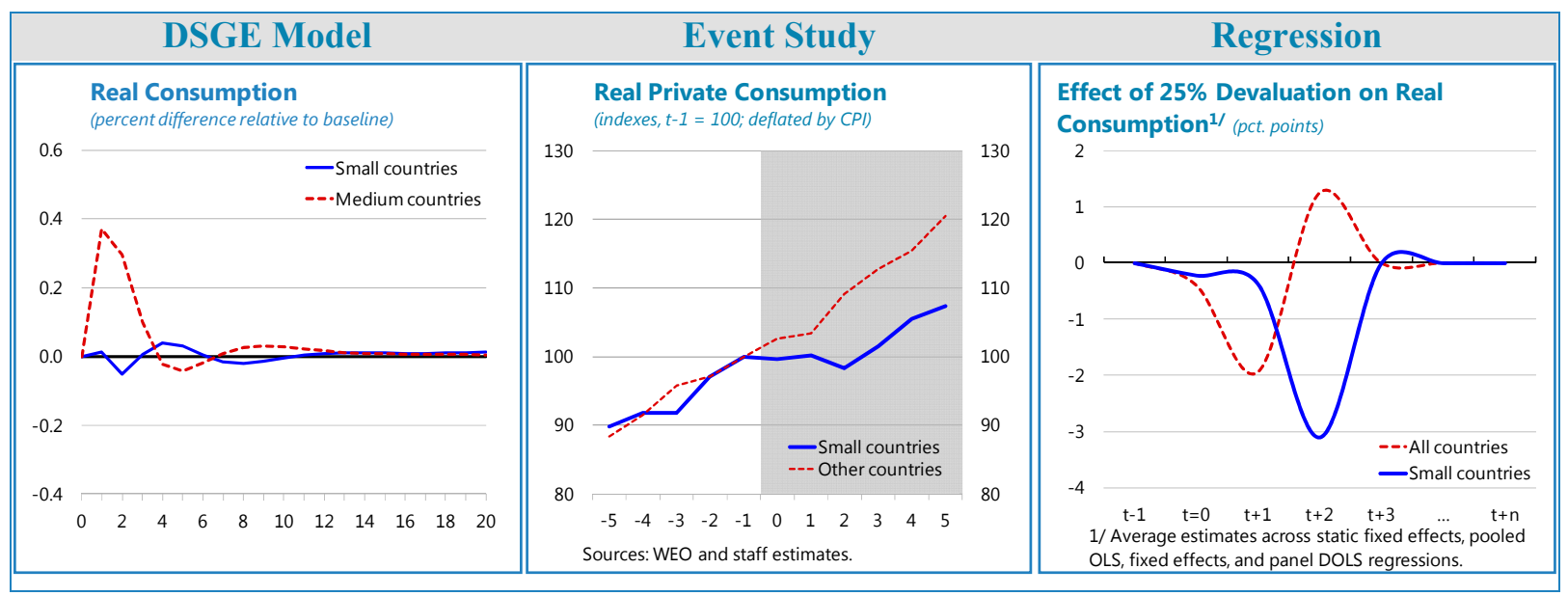

28. Model simulations provide some insight into the channels through which consumption may be particularly hard hit in smaller states. The contractionary effect comes from the decline in real wages in small states, which reduces the consumption of the liquidity constrained households in the short term given their inability to borrow to smooth consumption until wages recover. In turn, the decline in real wages in small states results from the stronger erosion of real wages more than offsetting the increase in nominal wages due to higher labor demand by firms. This is because in smaller states, firms face higher labor adjustment costs and post-

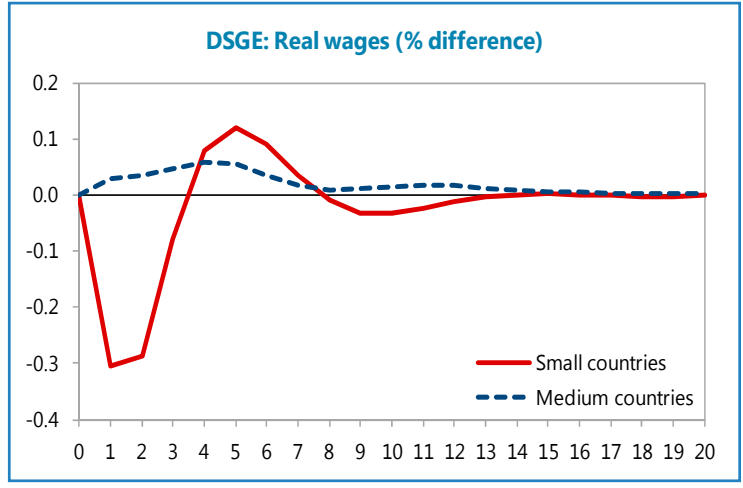
devaluation increases in the demand for labor are more muted as a result, with overall labor income falling in the short term and its increase is more muted over the medium and long-term.

\footnotetext{
${ }^{14}$ In the event studies, real government consumption also does not provide much impetus to growth in small countries post-devaluation. It decreases on average by a cumulative 5.6 percent between the year before devaluation and the second year after devaluation.
} 


\section{E. Investment}

29. Investment growth is strong on average in both groups of countries. However, it takes longer to manifest itself in small states: a less buoyant short-term response of investment in small states is consistent across the three studies. Average investment growth in small states tends to be low immediately following the devaluation, potentially reflecting either real adjustment rigidities or uncertainty generated by large changes of otherwise predominantly fixed parities. ${ }^{15}$ By contrast, investment in the larger countries begins to grow immediately, after several years of decline. However, over the medium run, investment growth in small states is very strong, averaging almost 10 percent in the three post-devaluation years.

30. Individual country experiences vary, but the strong increase in investment growth occurs in more than half of the small country sample. Among the small states, investment activity is frequently boosted by a pickup in foreign direct investment, higher official development assistance flows, and public sector infrastructure projects, each highlighting the importance of both favorable external conditions and strong policies to positive outcomes.

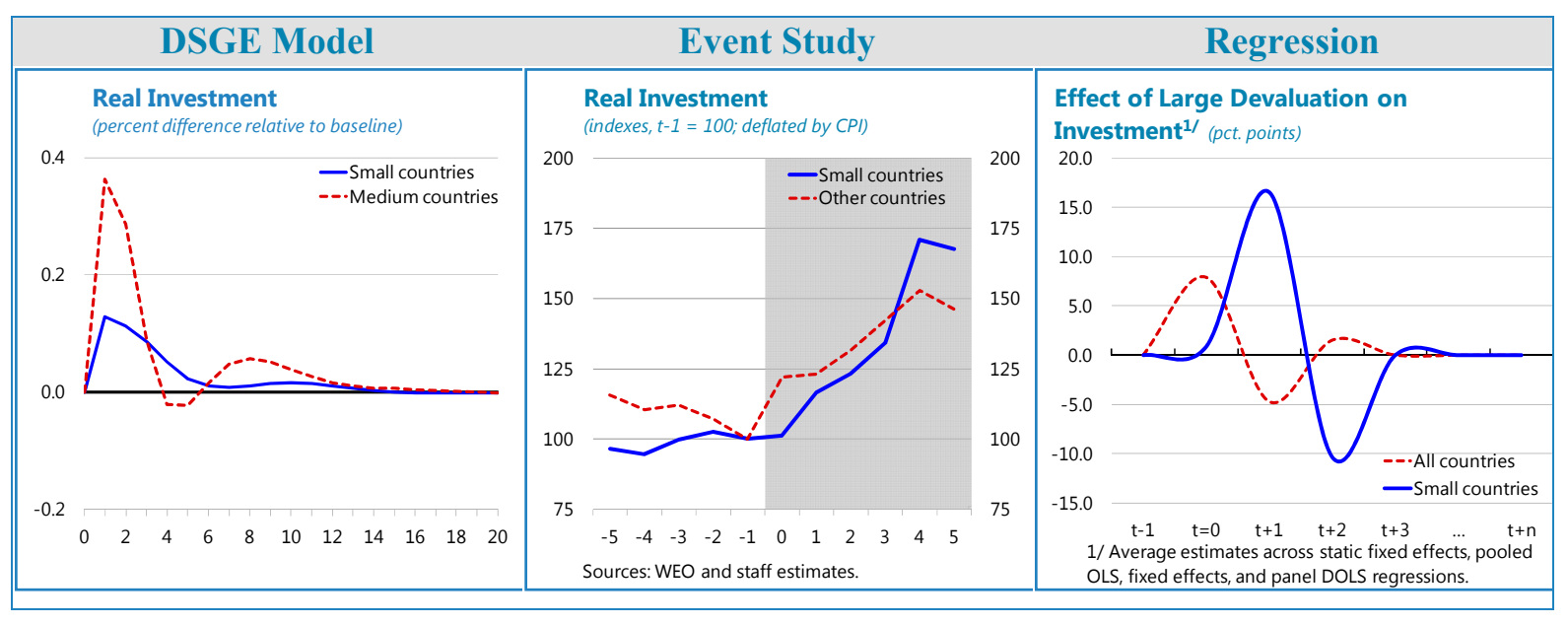

\section{F. External Balances}

31. Results suggest that the improvements in the current account in small states could be as strong, if not stronger, than in large states. The impetus for the improvement, however, comes mainly from a contraction or smaller growth in imports in the case of small states, while in the larger countries it primarily reflects export growth.

\footnotetext{
${ }^{15}$ In the model, for example, higher costs in adjusting input quantities lead to a smaller increase in imports of capital and intermediate goods by firms.
} 
32. The evidence on the impact of the devaluation on the current accounts is mixed, as in most of the literature. The current account (measured as a share of GDP) improves in about half of the cases in both small and larger states, and the improvement seems stronger in smaller states. On average, current account deficits in small countries improved by about 4 percentage points of GDP two years after the devaluation, relative to two years before, but the improvement started to reverse after the second post-devaluation year. The regression analysis broadly corroborates this finding, with exchange rate changes in small states estimated to result in a stronger immediate improvement in the current account, and followed by negative impacts two years later. While larger countries also experienced an immediate improvement followed by a medium-term deterioration, these movements

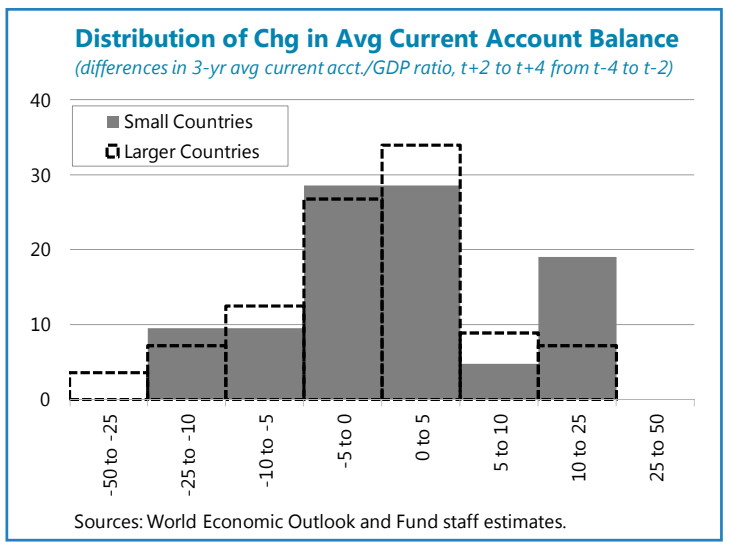
were of smaller magnitude.

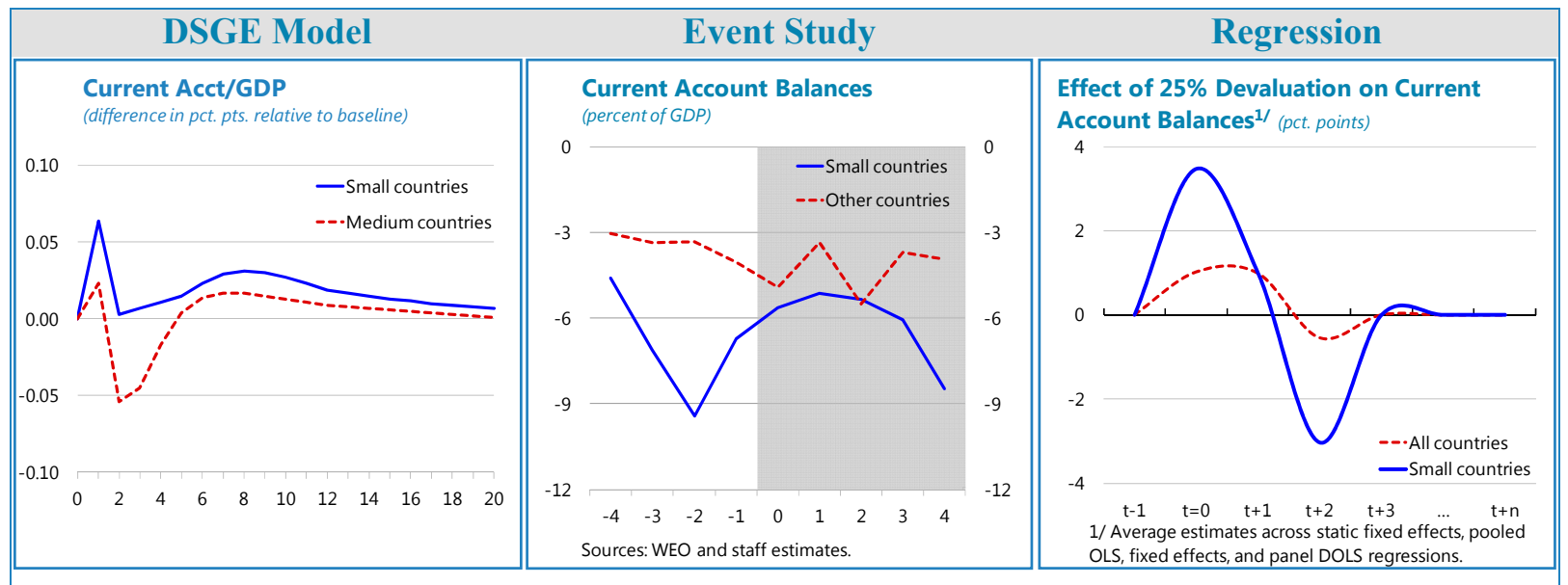

\section{Imports}

33. Import compression is generally more acute in the aftermath of the devaluations in small states, reflecting the more contractionary effects on consumption discussed above. In model simulations, imports increase modestly on impact reflecting the projected pickup in investment, but again the effect is significantly smaller for small states given the drag from the fall in the import of consumption goods in these states. 


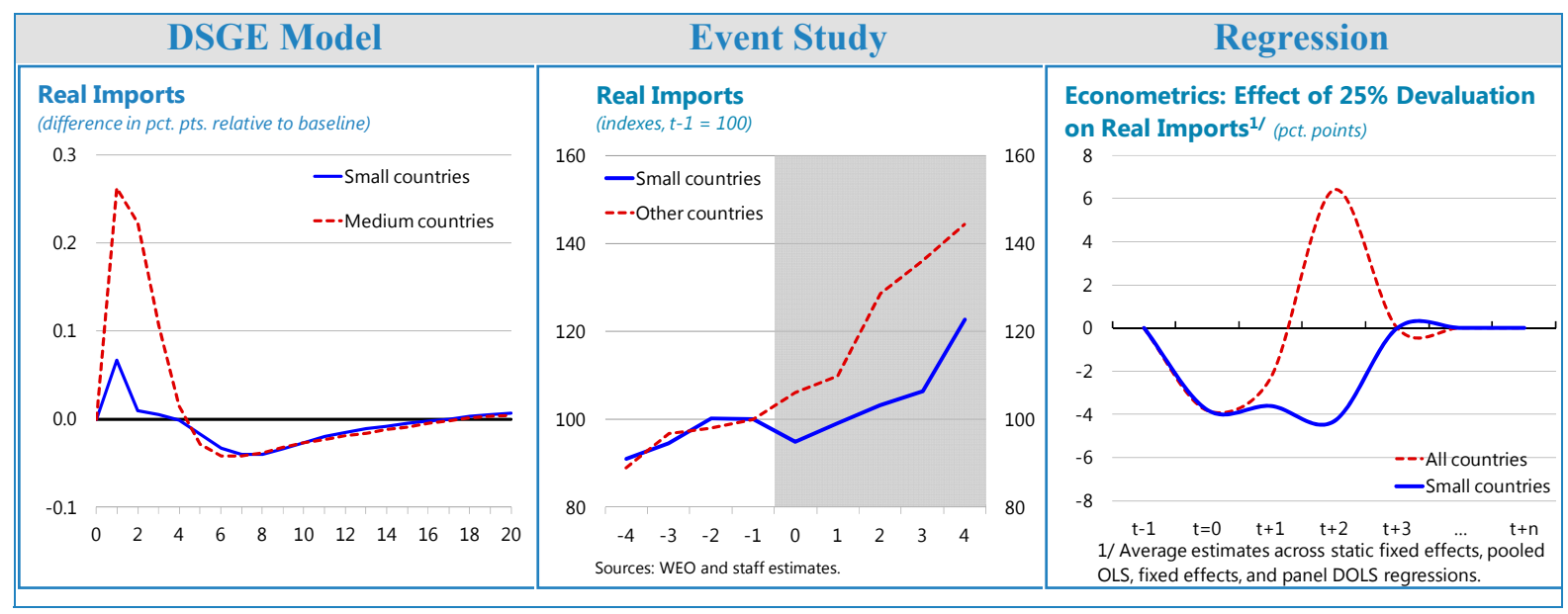

\section{Exports}

34. The pickup in exports, while strong in both small and larger states immediately after devaluations, flattens out earlier in small states than in larger ones. While the evidence suggests a strong immediate pickup in exports in small states, this appears to reflect the existence of capacity slack that could be utilized following devaluation. However, this effect is not sustained over the medium run, potentially reflecting the inability to scale up labor and other inputs due to small size and lack of skills. We did not find evidence that the effect of the devaluation lasts into the longer term, as the equilibrium level of exports is not significantly different from prior to the large devaluation.

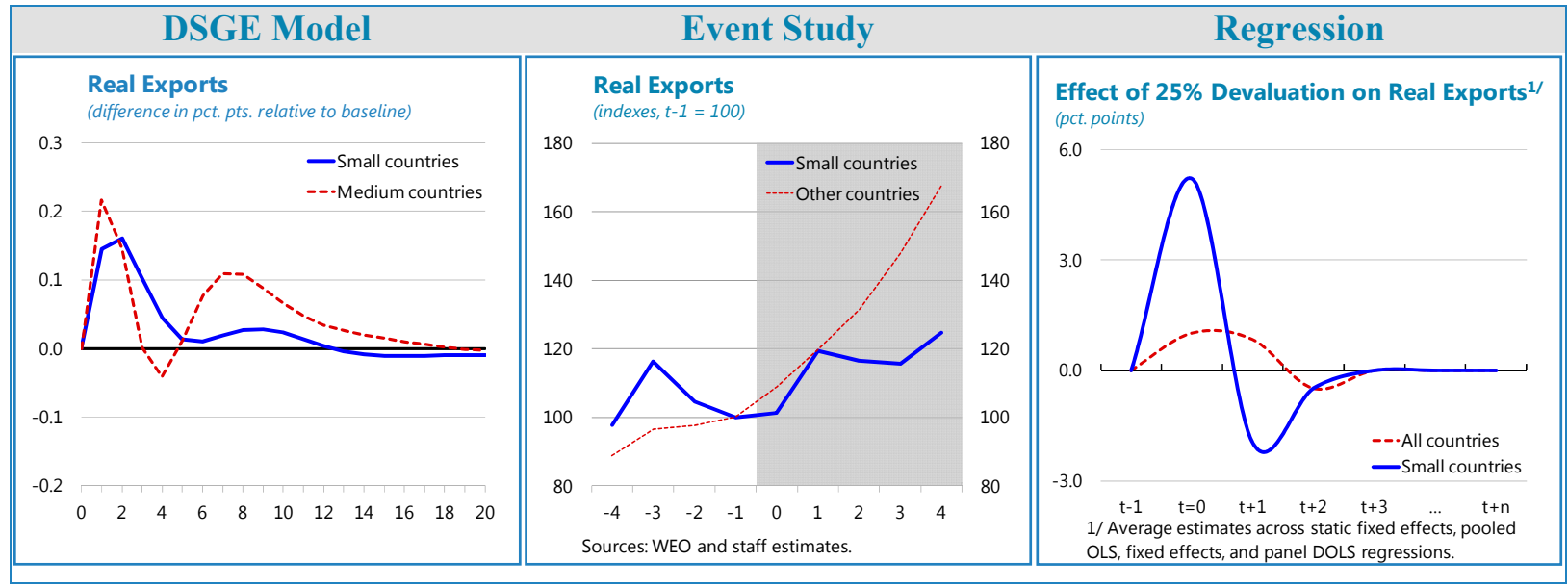


Box 2. Case Studies: Devaluations in Seychelles and Trinidad and Tobago

This box takes a closer look at three external devaluation cases in small states to help illustrate a range of possible outcomes that are harder to glean from average results reported in the sections above.

\section{Seychelles $(2007-08)^{1}$}

Prior to 2008, Seychelles fixed its exchange rate to the US dollar, buttressed by comprehensive exchange rate restrictions and surrender requirements. However, starting in the 1990s the peg came under increasing pressure, with rationing of scarce foreign exchange and an active parallel market, as expansionary fiscal and monetary policies became increasingly unsustainable. A series of step devaluations failed to restore stability. By 2007, the fiscal deficit had reached 8 percent of GDP, public debt 131 percent of GDP (two thirds of it foreign), reserves had fallen to two weeks of imports, and the parallel market rate was 55 percent above the official rate. Although the authorities undertook a small devaluation in 2006 and a large one in 2007, they proved insufficient to address the Seychelles' mounting macroeconomic challenges. In October 2008, strains intensified as Seychelles failed to make a payment on its external commercial debt.

At this point, the Seychellois authorities decided to abandon the peg for a managed float, as part of a comprehensive Fund-supported reform program. In late 2008, Seychelles became the smallest country with a floating exchange rate. There was some overshooting at first, but the currency began to appreciate by mid- 2009 (text figure). Inflation spiked at the end of 2008 and fell quickly thereafter, even with a brief bout of deflation by late 2009 as the currency strengthened. The initial depreciation facilitated a necessary consolidation in the current account deficit, predominantly driven by imports falling 11 percent as real incomes dropped.

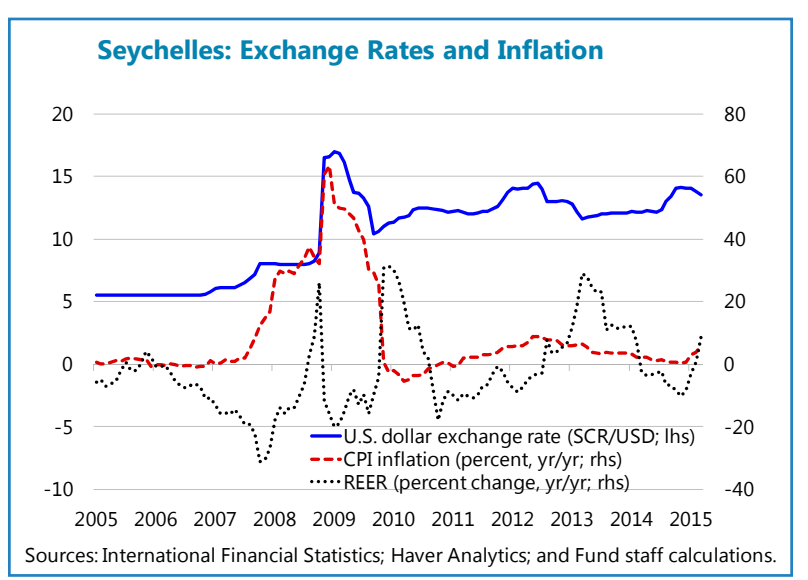

At the same time, Seychelles liberalized the foreign exchange market, lifting all restrictions on transactions. Monetary policy relied on a monetary anchor, buttressed by tight fiscal policy aiming to reduce public and external debt over time. Interventions in the foreign exchange market were to be limited to cases of excessive exchange rate volatility, or to meet reserve accumulation goals.

Seychelles has continued to maintain the managed float since 2009. The authorities have rebuilt gross reserves to over four months of import coverage, largely through opportunistic purchases of foreign exchange, and have twice managed foreign exchange pressures while maintaining overall macroeconomic stability. As external pressures weakened the current account balance and administered prices rose in the second half of 2011, currency depreciation and inflation developed, with some mutual reinforcement. An initial monetary tightening did not have its full desired impact, due to a weak transmission mechanism. By mid-2012, expectations appeared to have become unanchored, with increasing exchange rate volatility. At that point, the central bank intervened directly in the market through two unsterilized sales of foreign exchange, which helped support an appreciation of the currency and reduce inflationary pressures. After a subsequent 12-month period of stability in the nominal exchange rate, strong wage and credit growth coupled with weak export earnings again began to put pressure on the Rupee in mid-2014. This time, tight monetary policies, supported by fiscal restraint, were sufficient to stabilize the market following a nominal effective depreciation, and no direct interventions in the market were necessary. 
Box 2. Case Studies: Devaluations in Seychelles and Trinidad and Tobago (Continued)

Although an extremely small and open economy, Seychelles' experience suggests that exchange rate flexibility can play a supportive role in maintaining macroeconomic stability. In a highly open economy, both external and internal shocks can translate rapidly into significant weakening of the external position: the events of 2014, for example, demonstrated that large wage hikes, rapid credit growth and weak exports can spill over quickly into sizable external imbalances. Nominal depreciation provided a relatively quick mechanism to help to manage pressures, reduce absorption, and restore external equilibrium, with a carefully managed contraction of money supply. Under a fixed exchange rate, the necessary relative price adjustments could have required structural changes in goods and labor markets, with a contraction in money supply determined by circumstances.

Seychelles' experience also points to unavoidable challenges in successfully implementing a managed float in a small, open economy. The strong fiscal and monetary policies since the adoption of the managed float have been essential to its success. From 2009-14, primary fiscal surpluses have averaged 7 percent of GDP.

The strong fiscal anchor and the disciplined reserve accumulation helped to support the balance of payments and strengthen confidence, an essential ingredient for a successful managed float in a small, open economy. In particular, the foreign exchange market is very shallow; expectations are not strongly anchored and can easily become unhinged, leading to volatility. Moreover, in a tourism dependent economy, the short-run response of export revenues to depreciation is relatively muted, and more of the short-term adjustment falls on imports.

\section{Trinidad and Tobago (1985 and 1993)}

Trinidad and Tobago benefitted substantially from the large rise in prices for petroleum, its main export, over the $1970 \mathrm{~s}$ and early 1980s. GDP per capita in 1980 was about $6 \frac{1}{2}$ times its level a decade earlier and reserves were accumulating. However, as oil prices collapsed in 1983, growth contracted sharply, unemployment increased, and large fiscal and external deficits emerged. Nevertheless, the real effective exchange rate continued to appreciate (in line with high inflation), eroding competitiveness. By 1985, output was 15 percent below its 1982 peak, foreign reserves were 85

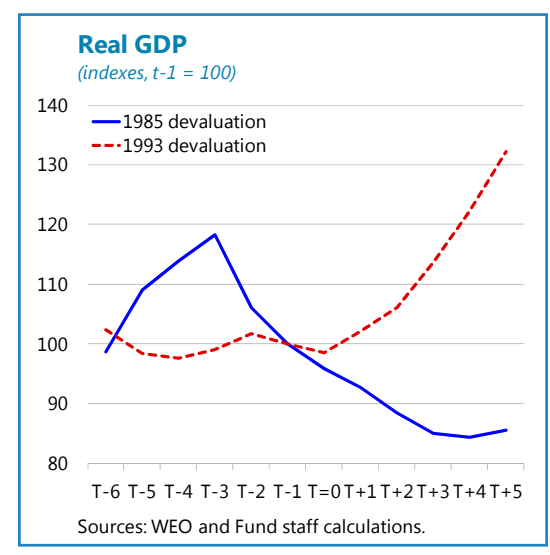
percent below their peak, and the unemployment rate had risen to 16 percent.

To restore competitiveness and growth, the authorities undertook a 33 percent nominal devaluation in December 1985 , supported by fiscal restraint. The adjustment involved deep cuts in public sector investment and wage restraint through the suspension of costs of living adjustments and merit increases, with subsequent attempts to lower nominal wages directly. However, some of the components of the wage policy were unwound, including by court decisions, and in the event the public sector wage bill rose on average. The financial system also came under stress, as hitherto poorly regulated institutions faced rising delinquencies, and real credit to the private sector decreased. In line with strains in the financial system and weak economic prospects, the private sector provided little offset to the decline in public

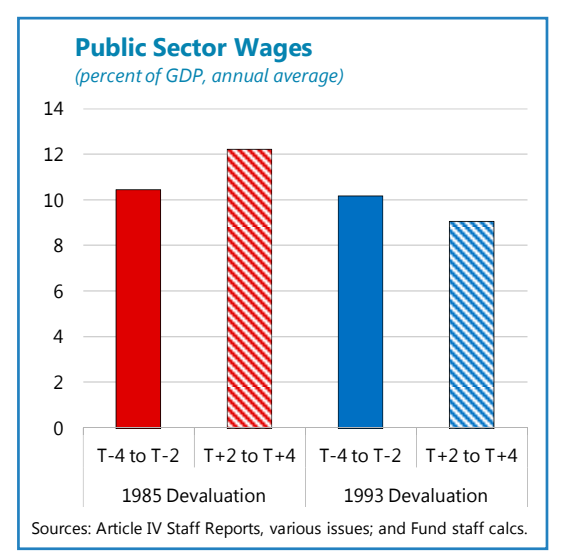
investment, and average investment rates in the post-devaluation period decreased significantly. 
Box 2. Case Studies: Devaluations in Seychelles and Trinidad and Tobago (Concluded)

A year following the devaluation, the real effective value of the Trinidad and Tobago dollar remained 16 percent above its 1980 level, reserves decreased further, and the recession persisted until 1989. With economic performance failing to gain momentum, in 1993 the government again undertook a nominal devaluation along with a number of structural reforms to help encourage stronger growth. During this episode, the government was able to maintain stronger control over public sector wages, with the wage bill decreasing in the postdevaluation period, and public sector investment remained close to the modest pre-devaluation levels. Tighter financial regulations helped maintain confidence in the financial system, and real deposits and private credit grew. The authorities undertook a series of structural reforms aimed at simplifying

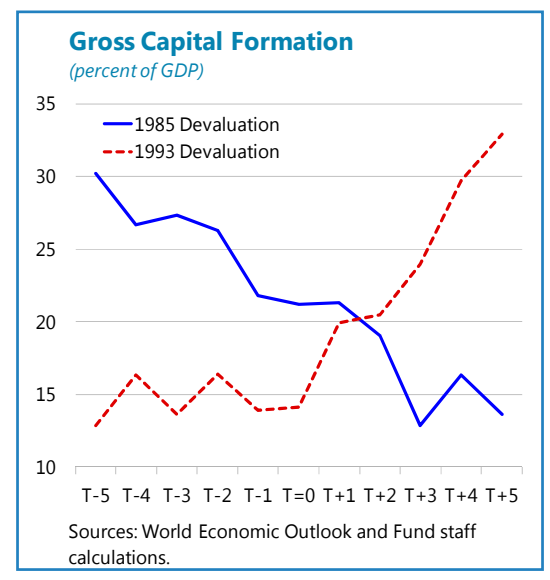
regulations, privatization, and reforming international trade and exchange restrictions. In this episode, output contracted lightly in 1993, but then began a robust expansion - by 1998, real GDP was about 32 percent above its pre-devaluation level, with reserves accumulating steadily.

${ }^{1}$ The Seychelles case study was prepared by Pietro Dallari and Joseph Thornton for an earlier version of this paper in IMF (2015).

\section{ConClusion AND Policy Implications}

35. The paper investigates the macroeconomic effect of large external devaluations, with a view to assessing whether devaluations can be a useful policy tool for small states. We find that whether a devaluation is contractionary or expansionary overall does not appear to be related to country size but to other factors at play. Devaluations can successfully boost growth in small states and improve the external position, as it did in slightly more than half of the devaluation cases in small states. Whether or not a devaluation is successful depends, instead, largely on the extent to which it is supported by strong conditions and policies, including a favorable external environment, a healthy financial system that can support credit growth, tight incomes policies to control inflation and a successful scale-up of investment.

36. While the growth impact of devaluation was not found to differ discernibly between large and small states, there was however a significant difference in the channels through which devaluation affects macroeconomic outcomes. In small states, consumption and imports tended to be lower (more expenditure compression than expenditure-switching), with some offset from a stronger investment response. More specifically:

- Consumption may be relatively harder hit in small states due to adverse income and distribution effects, combined with limited scope for import substitution or a rapid scaling up of the export sector due to size-related constraints. 
- The investment response can counteract the slack from weak consumption; and while it takes longer to manifest itself in small states, the medium and long-term response of investment is stronger.

- The improvement in the external current account may be initially stronger in small states, but in large part it is also due to a pronounced import compression.

37. The findings suggest that devaluations need not be ruled out as a policy tool in small states, although other tools can also be employed to address external imbalances, including internal devaluations and structural reforms. If external devaluations are pursued, our studies suggest that the following policy considerations should be kept in mind to increase the probability that it results in positive outcomes:

- Tight incomes policies after the devaluation-such as tight monetary and government wage policies - are crucial for containing inflation and preventing the cost-push inflation from taking hold more permanently. If wages and inflation are not brought under control quickly, the competitiveness gains from the nominal adjustment will be eroded and little adjustment in the real exchange rate will be achieved. While tight wage policies are certainly important in the public sector as the largest employer in many small states, economy-wide consensus on the need for wage restraint is also desirable.

- To avoid expenditure compression exacerbating poverty in the most vulnerable households, small countries should be particularly alert to these adverse effects and be ready to address them through appropriately targeted and efficient social safety nets.

- With the pick-up in investment providing the strongest boost to growth in expansionary devaluations, structural reforms to remove bottlenecks and stimulate post-devaluation investment are important. These reforms could also help address some of the factors underlying weak competitiveness in labor markets or policyinduced costs more generally.

- A favorable external environment is important in supporting growth following devaluations. To the degree that the devaluations could be undertaken when external demand is strong, exports and foreign direct investment would have a better chance at staging a strong response following the relative price change, hence supporting a better growth outcome.

- The devaluation and supporting policies should be credible enough to stem market perceptions of any further devaluation or policy adjustments. If the new parity or policies supporting it are not credible, the expectations of further devaluations or an increase in the sovereign risk premium would push domestic interest rates higher, imposing large costs in terms of investment, output contraction and financial instability. The conditions that may be required for credibility are that the devaluation is large enough to meaningfully address the overvaluation and that the fiscal position is sustainable. 
- Balance sheet effects could have a strongly contractionary effect if debts (public or private) are significantly dollarized. They could lead to a wave of bankruptcies, induce significant bank distress and an economic slowdown, and compromise the sustainability of the fiscal position. Consequently, the potential for these effects and the policy space to deal with their aftermath warrant policymakers' attention prior to any decision to undertake an external devaluation. It should be noted, however, that alternative adjustment tools, such as internal devaluations, could have equally detrimental balance sheet effects when the accompanying deflation increases the debt-servicing burden if economies are heavily indebted. 


\section{Annex I. Calibration Parameters of the GIMF Model}

This annex presents tables detailing parameter calibration and the specifics of the trade matrix for the four country groups used, which include small states, larger states, the U.S. and the rest of the world. The parameters of the model for the U.S. and the Rest of the World in both calibrations are based on the work of Kumhof, Laxton, Muir, and Mursula (2010) and Muir (2013). The parameters for the small countries are based on staff estimates for the Eastern Caribbean Currency Union (ECCU), and the parameters for the larger country are broadly based on the estimates for Peru.

Annex I. Table 1. GIMF Trade Matrix

(Percent of nominal GDP unless otherwise stated)

\begin{tabular}{|c|c|c|c|c|c|c|}
\hline & \multicolumn{3}{|c|}{ Matrix for small countries } & \multicolumn{3}{|c|}{ Matrix for medium countries } \\
\hline & Small & RW & US & Medium & RW & US \\
\hline GDP ( $\%$ of world nominal GDP) & 0.0 & 74.7 & 25.3 & 0.2 & 74.5 & 25.3 \\
\hline Population Size (\% of world) & 0.0 & 95.3 & 4.7 & 0.4 & 94.9 & 4.7 \\
\hline Aggregate Exports (EXPORTS) & 50.0 & 4.0 & 11.8 & 26.5 & 4.1 & 11.8 \\
\hline to Small / Medium & & 0.0 & 0.0 & & 0.1 & 0.0 \\
\hline to Rest of World & 30.9 & & 11.8 & 22.3 & & 11.8 \\
\hline to United States & 19.1 & 4.0 & & 4.2 & 4.0 & \\
\hline Final Goods (EXPORTS_D) & 45.7 & 2.6 & 8.0 & 6.2 & 2.6 & 8.0 \\
\hline to Small / Medium & & 0.0 & 0.0 & & 0.1 & 0.0 \\
\hline to Rest of World & 28.3 & & 7.9 & 4.6 & & 7.9 \\
\hline to United States & 17.4 & 2.6 & & 1.6 & 2.6 & \\
\hline Intermediate Goods (EXPORTS_T) & 4.3 & 1.4 & 3.9 & 20.3 & 1.4 & 3.9 \\
\hline to Small / Medium & & 0.0 & 0.0 & & 0.0 & 0.0 \\
\hline to Rest of World & 2.6 & & 3.9 & 17.7 & & 3.9 \\
\hline to United States & 1.7 & 1.4 & & 2.6 & 1.4 & \\
\hline Aggregate Imports (IMPORTS) & 50.0 & 4.0 & 11.8 & 26.5 & 4.1 & 11.8 \\
\hline from Small / Medium & & 0.0 & 0.0 & & 0.1 & 0.0 \\
\hline from Rest of World & 21.0 & & 11.8 & 22.3 & & 11.8 \\
\hline from United States & 29.0 & 4.0 & & 4.2 & 4.0 & \\
\hline Final Goods (IMPORTS_D) & 35.0 & 2.7 & 7.6 & 25.0 & 2.7 & 7.6 \\
\hline from Small / Medium & & 0.0 & 0.0 & & 0.0 & 0.0 \\
\hline from Rest of World & 12.0 & & 7.6 & 21.8 & & 7.6 \\
\hline from United States & 23.0 & 2.7 & & 3.2 & 2.7 & \\
\hline consumption goods (IMPORTS_C) & 24.5 & 1.5 & 5.4 & 21.1 & 1.5 & 5.4 \\
\hline investment goods (IMPORTS_I) & 10.5 & 1.2 & 2.3 & 3.9 & 1.2 & 2.3 \\
\hline Intermediate Goods (IMPORTS_T) & 15.0 & 1.3 & 4.2 & 1.5 & 1.4 & 4.2 \\
\hline from Small / Medium & & 0.0 & 0.0 & & 0.0 & 0.0 \\
\hline from Rest of World & 9.0 & & 4.2 & 0.5 & & 4.2 \\
\hline from United States & 6.0 & 1.3 & & 1.0 & 1.3 & \\
\hline \multicolumn{7}{|l|}{ Foreign Aid } \\
\hline Receipts (AIDREV) & 0.0 & 0.0 & 0.0 & 0.0 & 0.0 & 0.0 \\
\hline from Small / Medium & & 0.0 & 0.0 & & 0.0 & 0.0 \\
\hline from Rest of World & 0.0 & & 0.0 & 0.0 & & 0.0 \\
\hline from United States & 0.0 & 0.0 & & 0.0 & 0.0 & \\
\hline Payments (GOVAID) & 0.0 & 0.0 & 0.0 & 0.0 & 0.0 & 0.0 \\
\hline to Small / Medium & & 0.0 & 0.0 & & 0.0 & 0.0 \\
\hline to Rest of World & 0.0 & & 0.0 & 0.0 & & 0.0 \\
\hline to United States & 0.0 & 0.0 & & 0.0 & 0.0 & \\
\hline
\end{tabular}

Note: US identifies the United States, RW identifies the Rest of the World. 
Annex I. Table 2. GIMF: Macro Variables and Parameters

\begin{tabular}{|c|c|c|c|c|}
\hline Parameters & Small & Medium & RW & US \\
\hline \multicolumn{5}{|l|}{ Macro Variables } \\
\hline Annual inflation rate & 2.5 & 3.1 & 2.0 & 2.5 \\
\hline Habit persistance in consumption & 0.8 & 0.4 & 0.4 & 0.4 \\
\hline Government consumption to GDP ratio & 15.3 & 13.9 & 17.5 & 15.0 \\
\hline Government investment to GDP ratio & 6.5 & 5.0 & 2.0 & 2.5 \\
\hline Government tax revenue to GDP ratio & 20.7 & 15.9 & 29.0 & 28.3 \\
\hline Government debt to GDP ratio & 92.8 & 21.6 & 60.0 & 75.0 \\
\hline Investment to GDP ratio & 22.0 & 19.6 & 19.0 & 17.2 \\
\hline Consumption tax to GDP ratio & 15.8 & 6.5 & 10.0 & 4.6 \\
\hline Capital tax to GDP ratio & 2.0 & 6.0 & 3.3 & 3.2 \\
\hline Labor tax to GDP ratio & 2.8 & 1.7 & 20.5 & 17.6 \\
\hline \multicolumn{5}{|l|}{ Nominal Rigidities } \\
\hline Real Wage (PHI_P_U) & 40 & 40 & 47 & 40 \\
\hline Consumption Price (PHI_P_C) & 4 & 10 & 47 & 40 \\
\hline Investment Price (PHIP_I) & 4 & 10 & 47 & 40 \\
\hline Nontradables Price (PHI_P_N) & 4 & 10 & 47 & 40 \\
\hline Tradables Price (PHI_P_T) & 4 & 10 & 47 & 40 \\
\hline final goods (PHI_P_DM) & 4 & 10 & 30 & 40 \\
\hline intermediate goods (PHIP_TM) & 4 & 10 & 30 & 40 \\
\hline \multicolumn{5}{|l|}{ Real Adjustment Costs } \\
\hline Labor Demand (PHI_U) & 4 & 1 & 1 & 1 \\
\hline OLG Consumption (PHI_C_OLG) & 2 & 2 & 2 & 2 \\
\hline Consumption (PHI_C_LIQ $)$ & 1 & 1 & 1 & 1 \\
\hline Investment (PHII) & 1 & 1 & 1 & 1 \\
\hline \multicolumn{5}{|l|}{ Imports of } \\
\hline consumption goods (PHI_FC) & 4 & 1 & 1 & 1 \\
\hline investment goods (PHI_FI) & 4 & 1 & 1 & 1 \\
\hline tradable goods (PHIFT) & 4 & 1 & 1 & 1 \\
\hline \multicolumn{5}{|l|}{ Inflation Expectations } \\
\hline \multicolumn{5}{|l|}{ Weight on Inflation that is: } \\
\hline lead (1-UPSILON1-UPSILON2) & 1 & 1 & 1 & 1 \\
\hline lagged (UPSILON1) & 0 & 0 & 0 & 0 \\
\hline steady state (UPSILON2) & 0 & 0 & 0 & 0 \\
\hline \multicolumn{5}{|l|}{ Capacity Utilization (Curvature) } \\
\hline Nontradables (SIGACC_N) & 15 & 15 & 15 & 15 \\
\hline Tradables (SIGACC_T) & 15 & 15 & 15 & 15 \\
\hline \multicolumn{5}{|l|}{ Dividend Redistribution Factor } \\
\hline Entrepreneurs' Income (NWBUILD) & 0.5 & 0.5 & 0.5 & 0.5 \\
\hline \multicolumn{5}{|l|}{ Policy Rules } \\
\hline \multicolumn{5}{|l|}{ Monetary: Weight on the } \\
\hline lagged interest rate (DELTAI) & 1 & 1 & 0.3 & 0.3 \\
\hline \multicolumn{5}{|l|}{ inflation gap } \\
\hline core (DELTAPIE) & 0 & 0 & 1.2 & 1 \\
\hline \multicolumn{5}{|l|}{ weight on inflation: } \\
\hline contemporaneous (PIEWTO) & 0 & 0 & 0.25 & 0.25 \\
\hline 1 Periods Ahead (PIEWT1) & 1 & 1 & 0.75 & 0.75 \\
\hline nom. exchange rate target(DELTAE) & 100000 & 100000 & 0 & 0 \\
\hline NEER (DELTANEER) & 0 & 0 & 0 & 0 \\
\hline \multicolumn{5}{|l|}{ Fiscal: weight on excess } \\
\hline output gap (DAMP_GDPGAP) & 0.25 & 0.25 & 0.37 & 0.34 \\
\hline
\end{tabular}


Annex I. Table 3. GIMF: Parameters

\begin{tabular}{|c|c|c|c|c|}
\hline Parameters & Small & Medium & RW & US \\
\hline \multicolumn{5}{|l|}{ Elasticities of Substitution in Utility } \\
\hline Intertemporal (1/GAMMA) & 0.3 & 0.3 & 0.3 & 0.3 \\
\hline Labor and Consumption & 0.8 & 0.8 & 0.8 & 0.8 \\
\hline Elasticity of Labor Supply & 0.5 & 0.5 & 0.5 & 0.5 \\
\hline \multicolumn{5}{|l|}{ Other Structural Parameters } \\
\hline Habit Persistence (NU) & 0.8 & 0.4 & 0.4 & 0.4 \\
\hline Probability of Survival (THETA) & 1.0 & 1.0 & 1.0 & 1.0 \\
\hline Income Decline Rate (CHI) & 1.0 & 1.0 & 1.0 & 1.0 \\
\hline Marginal Propensity to Consume (MPC) & 4.2 & 5.2 & 4.9 & 5.3 \\
\hline Capital Depreciation (DEPKBAR) & 0.1 & 0.1 & 0.1 & 0.1 \\
\hline Share of LIQ Agents (PSI) & 0.5 & 0.5 & 0.3 & 0.3 \\
\hline \multicolumn{5}{|l|}{ Financial Accelerator } \\
\hline Borrower Riskiness & 0.5 & 0.5 & 0.5 & 0.5 \\
\hline Cost of Bankruptcy & 0.4 & 0.4 & 0.4 & 0.4 \\
\hline \multicolumn{5}{|l|}{ Elasticities of Substitution } \\
\hline Nontradables (SIGMA_N) & 11.0 & 11.0 & 11.0 & 11.0 \\
\hline Tradables (SIGMA_T) & 11.0 & 11.0 & 11.0 & 11.0 \\
\hline Retail (SIGMA_R) & 21.0 & 21.0 & 21.0 & 21.0 \\
\hline Consumption Goods (SIGMA_C) & 21.0 & 21.0 & 21.0 & 21.0 \\
\hline Investment Goods (SIGMA_I) & 21.0 & 21.0 & 21.0 & 21.0 \\
\hline Real Wages (SIGMA_U) & 11.0 & 11.0 & 11.0 & 11.0 \\
\hline Final Imports (SIGMA_DM) & 41.0 & 41.0 & 41.0 & 41.0 \\
\hline Intermediate Imports (SIGMA_TM) & 41.0 & 41.0 & 41.0 & 41.0 \\
\hline \multicolumn{5}{|l|}{ Markups on Price (in \%) } \\
\hline Nontradables (MUN) & 10.0 & 10.0 & 10.0 & 10.0 \\
\hline Tradables (MUT) & 10.0 & 10.0 & 10.0 & 10.0 \\
\hline Retail (MUR) & 5.0 & 5.0 & 5.0 & 5.0 \\
\hline Consumption (MUC) & 5.0 & 5.0 & 5.0 & 5.0 \\
\hline Investment (MUI) & 5.0 & 5.0 & 5.0 & 5.0 \\
\hline Real Wages (MUW) & 10.0 & 10.0 & 10.0 & 10.0 \\
\hline Final Imports & 2.5 & 2.5 & 2.5 & 2.5 \\
\hline Intermediate Imports & 2.5 & 2.5 & 2.5 & 2.5 \\
\hline \multicolumn{5}{|l|}{ Elasticities of Substitution } \\
\hline Home versus Foreign & 1.5 & 1.5 & 1.5 & 1.5 \\
\hline Among Foreign & 1.5 & 1.5 & 1.5 & 1.5 \\
\hline Tradable/Nontradable (XIA) & 0.5 & 0.5 & 0.5 & 0.5 \\
\hline Capital versus Labor & 1.0 & 1.0 & 1.0 & 1.0 \\
\hline \multicolumn{5}{|l|}{ Bias Parameters } \\
\hline \multicolumn{5}{|l|}{ Home Bias } \\
\hline consumption (ALPHA_CH) & 0.7 & 0.6 & 1.0 & 1.0 \\
\hline investment (ALPHA_IH) & 0.7 & 0.8 & 0.9 & 1.0 \\
\hline intermediate (ALPHA_TH) & 0.8 & 0.8 & 0.9 & 1.0 \\
\hline Nontraded vs Traded (ALPHA_N) & 0.5 & 0.7 & 0.6 & 0.5 \\
\hline \multicolumn{5}{|l|}{ Labor Over Capital } \\
\hline nontradables (ALPHA_N_U) & 0.7 & 0.7 & 0.7 & 0.7 \\
\hline tradables (ALPHA_T_U) & 0.5 & 0.5 & 0.5 & 0.5 \\
\hline
\end{tabular}

Note: US identifies the United States, RW identifies the Rest of the World. 


\section{Annex II. Regression Results}

Annex II. Table 1. Regression Results: Real GDP Growth

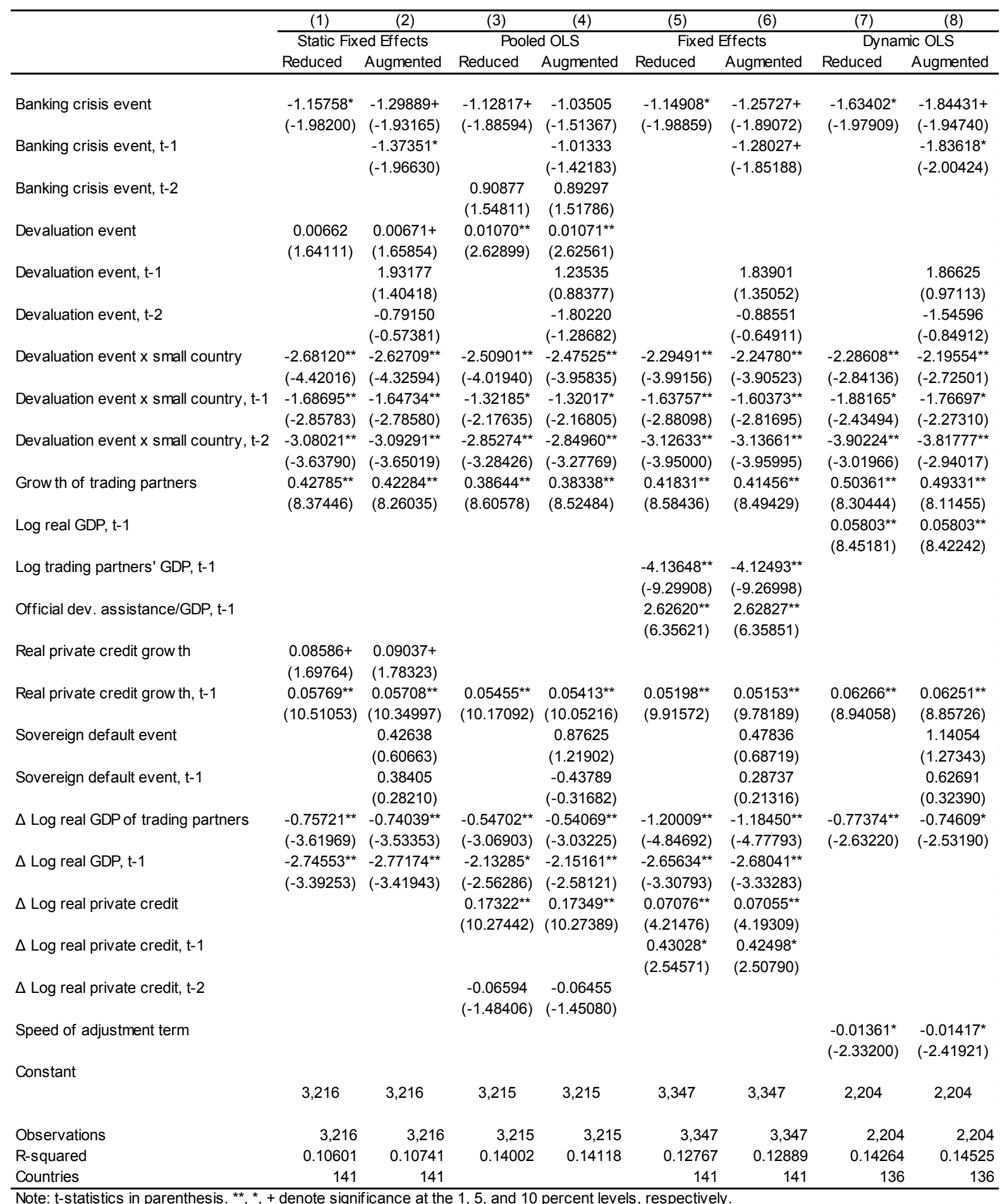

Note: t-statistics in parenthesis. ${ }^{* *},{ }^{*},+$ denote significance at the 1,5 , and 10 percent levels, respectively. 
Annex II. Table 2. Regression Results: Real Consumption Growth

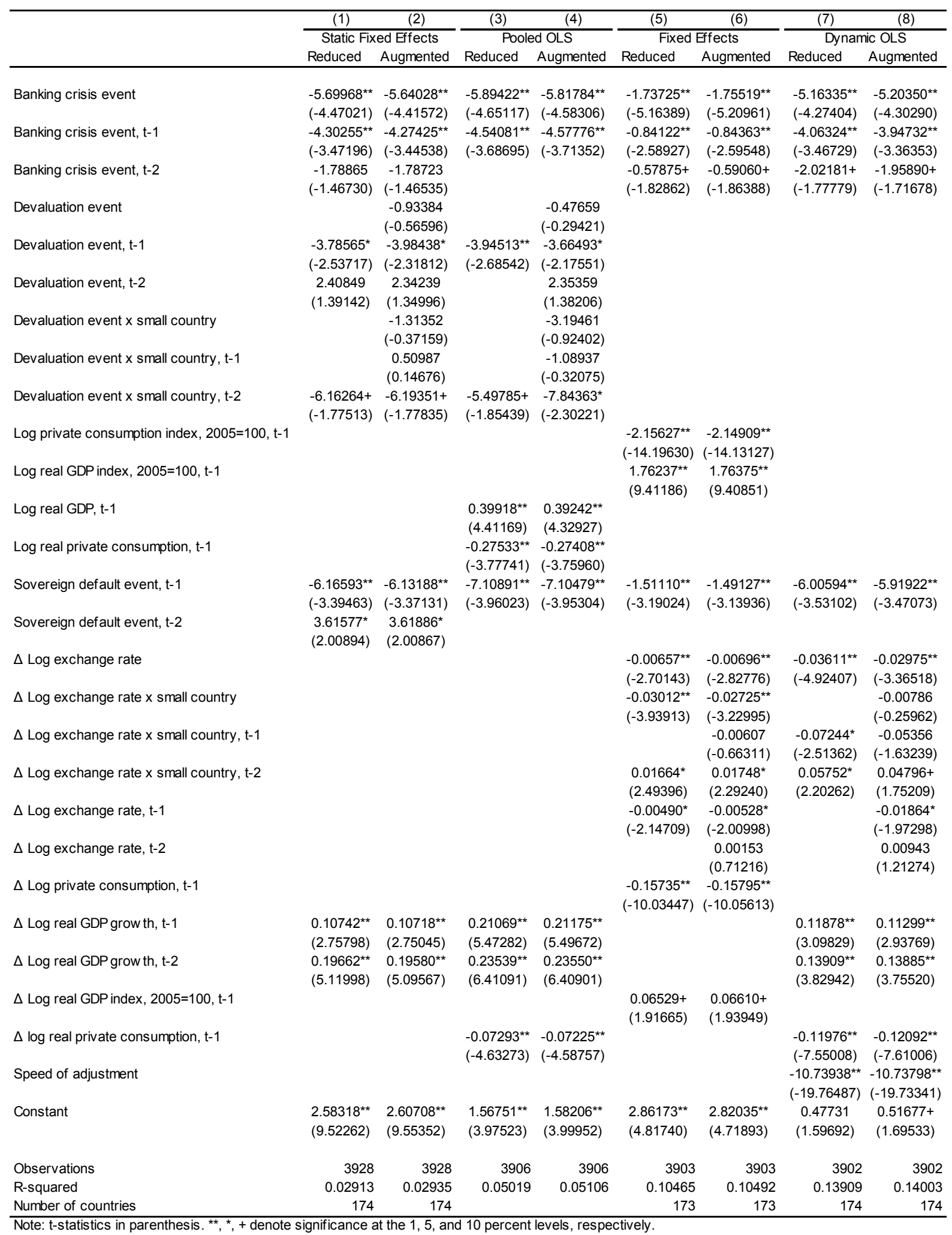


Annex II. Table 3. Regression Results: Real Investment

\begin{tabular}{|c|c|c|c|c|c|c|c|c|}
\hline & $(1)$ & $(2)$ & (3) & (4) & (5) & (6) & (7) & $(8)$ \\
\hline & \multicolumn{2}{|c|}{ Static Fixed Effects } & \multicolumn{2}{|c|}{ Pooled OLS } & \multicolumn{2}{|c|}{ Fixed Effects } & \multicolumn{2}{|c|}{ Dynamic OLS } \\
\hline & Reduced & Augmented & Reduced & Augmented & Reduced & Augmented & Reduced & Augmented \\
\hline \multirow[t]{2}{*}{ Banking crisis event } & $-7.57982^{\star *}$ & $-7.64384^{\star *}$ & $-7.51259^{* *}$ & $-7.41344^{\star *}$ & $-6.72510^{*}$ & $-6.72880^{*}$ & $-6.48232^{*}$ & $-6.38709^{*}$ \\
\hline & $(-2.58272)$ & $(-2.60410)$ & $(-2.66840)$ & $(-2.63222)$ & $(-2.42891)$ & $(-2.42949)$ & $(-2.33780)$ & $(-2.30253)$ \\
\hline \multirow[t]{2}{*}{ Banking crisis event, $\mathrm{t}-1$} & $-11.86775^{\star \star}$ & $-12.00185^{\star \star}$ & $-11.38573^{\star \star}$ & $-11.21206^{\star \star}$ & $-10.94652^{* *}$ & $-10.82825^{\star *}$ & $-10.98363^{\star *}$ & $-10.81507^{\star *}$ \\
\hline & $(-4.09782)$ & $(-4.14373)$ & $(-4.10004)$ & $(-4.03185)$ & $(-4.01742)$ & $(-3.96887)$ & $(-4.01621)$ & $(-3.94882)$ \\
\hline \multirow[t]{2}{*}{ Debt above 60 percent of GDP } & & & $-2.79662^{\star *}$ & $-2.76433^{* *}$ & $-5.75170^{\star *}$ & $-5.65644^{\star *}$ & $-3.36349^{\star *}$ & $-3.30764^{* *}$ \\
\hline & & & $(-3.39254)$ & $(-3.35164)$ & $(-4.87780)$ & $(-4.79178)$ & $(-3.43823)$ & $(-3.37609)$ \\
\hline \multirow[t]{2}{*}{ Devaluation event } & $6.72686^{*}$ & $8.94415^{\star *}$ & $8.92750^{\star *}$ & $8.83446^{\star *}$ & $5.06508+$ & $6.76350^{*}$ & $7.12642^{*}$ & $6.92034^{*}$ \\
\hline & (2.20975) & $(2.70797)$ & $(2.86356)$ & (2.83202) & $(1.78234)$ & $(2.19048)$ & $(2.30657)$ & (2.23120) \\
\hline \multirow[t]{2}{*}{ Devaluation event, $\mathrm{t}-1$} & $-5.85532+$ & -5.53920 & & -4.48642 & & -4.46501 & & -4.29991 \\
\hline & $(-1.70288)$ & $(-1.60802)$ & & $(-1.37598)$ & & $(-1.38688)$ & & $(-1.33043)$ \\
\hline \multirow[t]{2}{*}{ Devaluation event, $\mathrm{t}-2$} & & 3.34438 & & 1.04602 & & 0.64346 & & 1.02983 \\
\hline & & $(0.96422)$ & & $(0.31853)$ & & $(0.19835)$ & & $(0.31646)$ \\
\hline Devaluation event $x$ small country & & $\begin{array}{l}-13.86441 \\
(-1.62408)\end{array}$ & $\begin{array}{r}-14.00455+ \\
(-1.73740)\end{array}$ & $\begin{array}{r}-13.98287+ \\
(-1.73471)\end{array}$ & & $\begin{array}{l}-12.87418 \\
(-1.61693)\end{array}$ & $\begin{array}{r}-14.08497+ \\
(-1.76238)\end{array}$ & $\begin{array}{r}-13.91305+ \\
(-1.74008)\end{array}$ \\
\hline \multirow[t]{2}{*}{ Devaluation event, $\mathrm{t}-1 \mathrm{x}$ small country } & $24.01422^{\star *}$ & $23.18960^{* *}$ & $17.24423^{*}$ & $21.70045^{\star *}$ & $16.48431^{*}$ & $20.45608^{*}$ & $15.12484^{*}$ & $19.43362^{*}$ \\
\hline & (2.79235) & $(2.69365)$ & $(2.30802)$ & (2.66639) & $(2.24157)$ & (2.54672) & $(2.04704)$ & $(2.40907)$ \\
\hline \multirow[t]{2}{*}{ Devaluation event, $\mathrm{t}-2 \mathrm{x}$ small country } & $-15.97523^{*}$ & $-19.79359^{*}$ & $-12.42481+$ & $-13.56471+$ & -11.69555 & -12.86205 & $-13.07402+$ & $-14.14996+$ \\
\hline & $(-2.02587)$ & $(-2.29725)$ & $(-1.66032)$ & $(-1.66275)$ & $(-1.58775)$ & $(-1.59670)$ & $(-1.76697)$ & $(-1.74941)$ \\
\hline \multirow[t]{2}{*}{ Log consumption, deflated by CPI, t-1 } & & & $5.01187^{\star *}$ & $5.02494^{\star *}$ & $11.76102^{\star \star}$ & $11.80278^{\star *}$ & & \\
\hline & & & (7.73207) & $(7.74393)$ & $(5.78738)$ & $(5.80813)$ & & \\
\hline \multirow[t]{2}{*}{ Log investment, deflated by CPI, t-1 } & & & $-5.41781^{* *}$ & $-5.42917^{\star *}$ & $-21.93804^{\star *}$ & $-21.91787^{\star *}$ & & \\
\hline & & & $(-8.21188)$ & $(-8.22050)$ & $(-17.15661)$ & $(-17.14541)$ & & \\
\hline \multirow[t]{2}{*}{ Log private credit, deflated by CPI, t-1 } & & & & & $1.56275+$ & 1.52031 & & \\
\hline & & & & & $(1.65380)$ & $(1.60818)$ & & \\
\hline \multirow[t]{2}{*}{ Log real exports } & & & $0.69023^{* *}$ & $0.69412^{* *}$ & $4.10480^{* *}$ & $4.14733^{* *}$ & & \\
\hline & & & $(3.16193)$ & $(3.17763)$ & $(3.68566)$ & $(3.71820)$ & & \\
\hline \multirow[t]{2}{*}{ Sovereign default event } & $-14.86478^{* *}$ & $-14.80577^{\star *}$ & $-13.26826^{\star *}$ & $-13.37482^{* *}$ & $-13.49033^{* *}$ & $-13.62909^{\star *}$ & $-12.99979^{* *}$ & $-13.12283^{* *}$ \\
\hline & $(-3.48967)$ & $(-3.47612)$ & $(-3.28096)$ & $(-3.30613)$ & $(-3.36821)$ & $(-3.40227)$ & $(-3.25094)$ & $(-3.27961)$ \\
\hline \multirow[t]{2}{*}{ Sovereign default event, $\mathrm{t}-1$} & $-13.78223^{\star *}$ & $-13.89790^{* *}$ & $-12.86136^{* *}$ & $-12.99108^{* *}$ & $-14.67160^{\star *}$ & $-15.00192^{* *}$ & $-13.97443^{\star *}$ & $-14.11353^{* *}$ \\
\hline & $(-3.15854)$ & $(-3.18410)$ & $(-3.10303)$ & $(-3.13275)$ & $(-3.58247)$ & $(-3.66061)$ & $(-3.41042)$ & $(-3.44180)$ \\
\hline \multirow[t]{2}{*}{$\Delta$ Log investment deflated by CPI, t-1 } & & & $-0.13892^{\star *}$ & $-0.13752^{\star *}$ & $-0.07912^{\star \star}$ & $-0.07834^{\star \star}$ & $-0.07988^{\star *}$ & $-0.07874^{\star *}$ \\
\hline & & & $(-7.70358)$ & $(-7.61215)$ & $(-4.29859)$ & $(-4.25017)$ & $(-4.33354)$ & $(-4.26418)$ \\
\hline \multirow[t]{2}{*}{$\Delta$ Log private consumption, deflated by CPI } & -0.00110 & -0.00330 & $0.11009^{* *}$ & $0.10838^{* *}$ & $0.09255^{*}$ & $0.08962^{*}$ & $0.14019^{* *}$ & $0.13835^{\star *}$ \\
\hline & $(-0.02875)$ & $(-0.08643)$ & $(2.96381)$ & $(2.91518)$ & $(2.43518)$ & $(2.35678)$ & $(3.81981)$ & (3.76613) \\
\hline$\Delta$ Log private credit, deflated by $\mathrm{CPI}, \mathrm{t}-1$ & $0.23145^{\star \star}$ & $0.23231^{\star *}$ & $0.26267^{\star *}$ & $0.26026^{* *}$ & $0.25723^{\star *}$ & $0.25465^{\star *}$ & $0.25191^{\star *}$ & $0.24972^{* *}$ \\
\hline & $(8.67470)$ & (8.70518) & $(10.27347)$ & (10.14785) & $(9.88462)$ & (9.75911) & (9.91274) & $(9.80077)$ \\
\hline$\Delta$ Log real exports & $0.19290^{* *}$ & $0.19205^{\star \star}$ & $0.21147^{\star \star}$ & $0.21265^{\star \star}$ & $0.20648^{\star *}$ & $0.20763^{\star *}$ & $0.20617^{\star \star}$ & $0.20695^{\star \star}$ \\
\hline & $(5.83153)$ & $(5.80551)$ & $(6.80486)$ & $(6.83482)$ & (6.54944) & (6.58193) & $(6.61127)$ & $(6.63240)$ \\
\hline Speed of adjustment & & & & & & & $-21.24414^{* \star}$ & $-21.23758^{\star \star}$ \\
\hline & & & & & & & $(-16.83279)$ & $(-16.82636)$ \\
\hline Constant & $1.96987^{\star *}$ & $1.92789^{\star \star}$ & $-3.54194^{\star *}$ & $-3.53870^{\star *}$ & 0.81629 & 0.73896 & $-29.55075^{\star \star}$ & $-29.51080^{* *}$ \\
\hline & (3.97444) & $(3.86681)$ & $(-2.89156)$ & $(-2.88880)$ & $(0.11379)$ & $(0.10299)$ & $(-14.10536)$ & $(-14.08372)$ \\
\hline Observations & 2,941 & 2,941 & 2,894 & 2,894 & 2,894 & 2,894 & 2,894 & 2,894 \\
\hline R-squared & 0.07353 & 0.07469 & 0.12751 & 0.12812 & 0.1973 & 0.19867 & 0.18984 & 0.19041 \\
\hline Number of countries & 134 & 134 & & & 134 & 134 & 134 & 134 \\
\hline
\end{tabular}

Note: t-statistics in parenthesis. ${ }^{* *},{ }^{*},+$ denote significance at the 1,5 , and 10 percent levels, respectively. 
Annex II. Table 4. Regression Results: Real Exports

\begin{tabular}{|c|c|c|c|c|c|c|c|c|}
\hline & (1) & (2) & (3) & (4) & (5) & (6) & (7) & (8) \\
\hline & \multicolumn{2}{|c|}{ Static Fixed Effects } & \multicolumn{2}{|c|}{ Pooled OLS } & \multicolumn{2}{|c|}{ Fixed Effects } & \multicolumn{2}{|c|}{ Dynamic OLS } \\
\hline & Reduced & Augmented & Reduced & Augmented & Reduced & Augmented & Reduced & Augmented \\
\hline Banking crisis event & & & & & & & $\begin{array}{c}-2.91144+ \\
(-1.78623)\end{array}$ & $\begin{array}{l}-2.92485+ \\
(-1.79379)\end{array}$ \\
\hline Banking crisis event, $\mathrm{t}-2$ & & & $\begin{array}{l}4.07087^{\star *} \\
(2.65588)\end{array}$ & $\begin{array}{l}4.07498^{\star *} \\
(2.65794)\end{array}$ & $\begin{array}{c}3.39098^{*} \\
(2.23787)\end{array}$ & $\begin{array}{r}3.39295^{*} \\
(2.23851)\end{array}$ & $\begin{array}{r}3.26127^{*} \\
(2.14905)\end{array}$ & $\begin{array}{r}3.27052^{*} \\
(2.15458)\end{array}$ \\
\hline Log real GDP of trading partners, $\mathrm{t}-1$ & & & $\begin{array}{c}0.01565+ \\
(1.69043)\end{array}$ & $\begin{array}{r}0.01558+ \\
(1.68135)\end{array}$ & $\begin{array}{l}0.11292^{\star *} \\
(7.46750)\end{array}$ & $\begin{array}{l}0.11287^{* *} \\
(7.45746)\end{array}$ & & \\
\hline Log real net exports, $\mathrm{t}-1$ & & & & & $\begin{array}{l}-6.29512^{* *} \\
(-9.50264)\end{array}$ & $\begin{array}{l}-6.29479^{* *} \\
(-9.50047)\end{array}$ & & \\
\hline Log relative price index, $\mathrm{t}-1$ & & & & & $\begin{array}{l}0.58105^{\star *} \\
(2.65056)\end{array}$ & $\begin{array}{l}0.58138^{* *} \\
(2.65117)\end{array}$ & & \\
\hline Sovereign default event & & & $\begin{array}{l}-4.43574+ \\
(-1.73758)\end{array}$ & $\begin{array}{l}-4.43263+ \\
(-1.73608)\end{array}$ & & & & \\
\hline Sovereign default event, $\mathrm{t}-1$ & & & $\begin{array}{l}-7.98408^{* *} \\
(-3.26938)\end{array}$ & $\begin{array}{l}-7.96663^{* *} \\
(-3.25962)\end{array}$ & $\begin{array}{l}-6.37174^{* *} \\
(-2.61930)\end{array}$ & $\begin{array}{l}-6.36386^{* *} \\
(-2.61335)\end{array}$ & $\begin{array}{l}-7.07431^{* *} \\
(-2.92199)\end{array}$ & $\begin{array}{l}-7.03397^{\text {** }} \\
(-2.90212)\end{array}$ \\
\hline Sovereign default event, $\mathrm{t}-2$ & & & & & $\begin{array}{c}4.03717+ \\
(1.67593)\end{array}$ & $\begin{array}{c}4.03614+ \\
(1.67522)\end{array}$ & & \\
\hline$\Delta$ Log exchange rate & $\begin{array}{l}0.05468^{* *} \\
(2.75911)\end{array}$ & $\begin{array}{r}0.04226^{*} \\
(2.07202)\end{array}$ & $\begin{array}{c}0.03462+ \\
(1.70492)\end{array}$ & $\begin{array}{c}0.03438+ \\
(1.69005)\end{array}$ & $\begin{array}{c}0.04686^{*} \\
(2.29784)\end{array}$ & $\begin{array}{c}0.04679^{*} \\
(2.29217)\end{array}$ & $\begin{array}{c}0.03788+ \\
(1.86237)\end{array}$ & $\begin{array}{c}0.03758+ \\
(1.84597)\end{array}$ \\
\hline$\Delta$ Log exchange rate, $\mathrm{t}-1$ & $\begin{array}{l}0.03328^{\star *} \\
(2.85594)\end{array}$ & $\begin{array}{l}0.03552^{* *} \\
(2.84856)\end{array}$ & $\begin{array}{l}0.03436^{* *} \\
(2.61898)\end{array}$ & $\begin{array}{c}0.03400^{*} \\
(2.56629)\end{array}$ & $\begin{array}{l}0.03361^{* *} \\
(2.58841)\end{array}$ & $\begin{array}{c}0.03349^{*} \\
(2.56052)\end{array}$ & $\begin{array}{r}0.03137^{*} \\
(2.41802)\end{array}$ & $\begin{array}{r}0.03079 * \\
(2.35596)\end{array}$ \\
\hline$\Delta$ Log exchange rate, $\mathrm{t}-2$ & & $\begin{array}{r}-0.01569 \\
(-1.64520)\end{array}$ & $\begin{array}{r}-0.02019^{*} \\
(-2.05385)\end{array}$ & $\begin{array}{l}-0.01970+ \\
(-1.94189)\end{array}$ & $\begin{array}{l}-0.01812+ \\
(-1.82991)\end{array}$ & $\begin{array}{l}-0.01792+ \\
(-1.75245)\end{array}$ & $\begin{array}{c}-0.02457^{*} \\
(-2.49350)\end{array}$ & $\begin{array}{c}-0.02358^{*} \\
(-2.31252)\end{array}$ \\
\hline$\Delta$ Log exchange rate $\mathrm{x}$ small country & $\begin{array}{l}0.15888^{\star *} \\
(3.81418)\end{array}$ & $\begin{array}{l}0.17130^{* *} \\
(4.01888)\end{array}$ & $\begin{array}{l}0.16802^{* *} \\
(4.04423)\end{array}$ & $\begin{array}{l}0.16788^{\star *} \\
(4.03958)\end{array}$ & $\begin{array}{l}0.16840^{* *} \\
(4.02469)\end{array}$ & $\begin{array}{l}0.16815^{\star *} \\
(4.00611)\end{array}$ & $\begin{array}{l}0.16476^{\star *} \\
(3.92588)\end{array}$ & $\begin{array}{l}0.16355^{\star \star} \\
(3.88520)\end{array}$ \\
\hline$\Delta$ Log exchange rate, $\mathrm{t}-1 \mathrm{x}$ small country & $\begin{array}{l}-0.11268^{* *} \\
(-2.92098)\end{array}$ & $\begin{array}{l}-0.11922^{* *} \\
(-2.59412)\end{array}$ & $\begin{array}{l}-0.12177^{* *} \\
(-3.04149)\end{array}$ & $\begin{array}{c}-0.11719^{*} \\
(-2.52878)\end{array}$ & $\begin{array}{l}-0.10552^{* *} \\
(-2.60720)\end{array}$ & $\begin{array}{c}-0.10393^{*} \\
(-2.28939)\end{array}$ & $\begin{array}{l}-0.11724^{* *} \\
(-2.89065)\end{array}$ & $\begin{array}{l}-0.10941^{*} \\
(-2.40278)\end{array}$ \\
\hline$\Delta$ Log exchange rate, $\mathrm{t}-2 \mathrm{x}$ small country & & $\begin{array}{r}-0.00142 \\
(-0.03673)\end{array}$ & & $\begin{array}{r}-0.00743 \\
(-0.19629)\end{array}$ & & $\begin{array}{r}-0.00295 \\
(-0.07732)\end{array}$ & & $\begin{array}{r}-0.01446 \\
(-0.37802)\end{array}$ \\
\hline$\Delta$ Log real exports, $\mathrm{t}-1$ & & & $\begin{array}{l}-0.05762^{* *} \\
(-3.44040)\end{array}$ & $\begin{array}{l}-0.05774^{* *} \\
(-3.44481)\end{array}$ & $\begin{array}{c}-0.08524^{\star *} \\
(-5.01265)\end{array}$ & $\begin{array}{l}-0.08528^{* *} \\
(-5.01138)\end{array}$ & $\begin{array}{l}-0.09395^{\star *} \\
(-5.54105)\end{array}$ & $\begin{array}{l}-0.09416^{\star *} \\
(-5.54981)\end{array}$ \\
\hline$\Delta$ Log real GDP of trading partners & $\begin{array}{r}1.50765^{\star *} \\
(11.26405)\end{array}$ & $\begin{array}{r}1.49064^{* *} \\
(10.97160)\end{array}$ & $\begin{array}{l}1.07595^{\star \star} \\
(9.44886)\end{array}$ & $\begin{array}{l}1.07643^{\star *} \\
(9.44956)\end{array}$ & $\begin{array}{r}1.48868^{\star \star} \\
(10.88581)\end{array}$ & $\begin{array}{r}1.48866^{* *} \\
(10.88395)\end{array}$ & $\begin{array}{l}1.35185^{\star *} \\
(9.98597)\end{array}$ & $\begin{array}{l}1.35207^{* \star} \\
(9.98617)\end{array}$ \\
\hline$\Delta$ Log relative price index, $\mathrm{t}-1$ & $\begin{array}{l}-0.10107^{* *} \\
(-4.12509)\end{array}$ & $\begin{array}{l}-0.08152^{\star *} \\
(-3.21978)\end{array}$ & $\begin{array}{c}-0.05933^{*} \\
(-2.36805)\end{array}$ & $\begin{array}{c}-0.05914^{*} \\
(-2.35835)\end{array}$ & $\begin{array}{l}-0.06982^{* *} \\
(-2.66962)\end{array}$ & $\begin{array}{l}-0.06976^{* *} \\
(-2.66556)\end{array}$ & $\begin{array}{c}-0.05122^{*} \\
(-1.98632)\end{array}$ & $\begin{array}{r}-0.05095^{*} \\
(-1.97463)\end{array}$ \\
\hline Speed of adjustment & & & & & & & $\begin{array}{l}-4.66757^{\star *} \\
(-8.42317)\end{array}$ & $\begin{array}{l}-4.67175^{\star \star} \\
(-8.42792)\end{array}$ \\
\hline Constant & $\begin{array}{r}-0.14868 \\
(-0.27458)\end{array}$ & $\begin{array}{r}0.02361 \\
(0.04279)\end{array}$ & $\begin{array}{r}0.47241 \\
(0.47613)\end{array}$ & $\begin{array}{r}0.47863 \\
(0.48208)\end{array}$ & $\begin{array}{r}17.48147^{* *} \\
(7.19583)\end{array}$ & $\begin{array}{r}17.48333^{\star *} \\
(7.19513)\end{array}$ & $\begin{array}{l}6.71335^{\star \star} \\
(7.41222)\end{array}$ & $\begin{array}{l}6.72194^{\star \star} \\
(7.41838)\end{array}$ \\
\hline Observations & 3,526 & 3,450 & 3,410 & 3,410 & 3,410 & 3,410 & 3,410 & 3,410 \\
\hline R-squared & 0.0459 & 0.0451 & 0.04303 & 0.04304 & 0.08939 & 0.0894 & 0.08249 & 0.08253 \\
\hline Number of countries & 157 & 157 & & & 157 & 157 & 157 & 157 \\
\hline
\end{tabular}




\section{Annex II. Table 5. Regression Results: Real Imports}

Banking crisis event

Banking crisis event, t-1

Banking crisis event, t-2

Devaluation event

Devaluation event, t-1

Devaluation event, $\mathrm{t}-2$

Devaluation event $x$ small country

Devaluation eventx small country, $\mathrm{t}-1$

Devaluation event $x$ small country, $t-2$

Log real consumption, t-1

Log real imports, t-1

Log real investment, t-1

Log relative price index, $2005=100 ; \mathrm{t}-1$

Sovereign default event

Sovereign default event, t-2

$\Delta$ Log exchange rate

$\Delta$ Log exchange rate $x$ small country

$\Delta$ Log exchange rate $\mathrm{x}$ small country, $\mathrm{t}-1$

$\Delta$ Log exchange rate $\mathrm{x}$ small country, $\mathrm{t}-2$

$\Delta$ Log exchange rate, $\mathrm{t}-1$

$\Delta$ Log exchange rate, $\mathrm{t}-2$

$\Delta$ Log real consumption

$\Delta$ Log real imports, $\mathrm{t}-1$

$\Delta$ Log real investment

$\Delta$ Log relative price index, $2005=100$

$\Delta$ Official dev. assistance/GDP

$\Delta$ Official dev. assistance/GDP, t-1

$\Delta$ Official dev. assistance/GDP, t-2

Speed of adjustment

Constant

Observations

R-squared

Number of countries

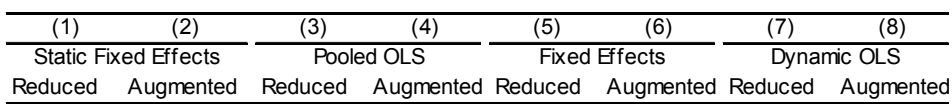

$-4.75287^{\star *}-4.60341^{\star *} \quad-4.32735^{\star *}-4.21255^{\star *} \quad-4.96486^{*}-4.66909^{*} \quad-4.24565^{*}-4.15692+$

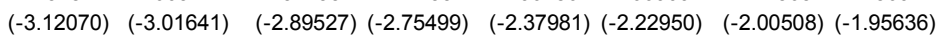

$-3.82846^{\star *}-3.73617^{*} \quad-3.33791^{*}-3.49615^{*} \quad-4.43638^{*}-4.41903^{*} \quad-3.72718+-3.76596+$

$\begin{array}{lllllll}(-2.63622) & (-2.56698) & (-2.34329) & (-2.39955) & (-2.28611) & (-2.23923) & (-1.86921) \\ (-1.88248)\end{array}$

$4.10108^{* *} 4.19423^{* *} \quad 4.45404^{* *} 4.32364^{* *}$

$\begin{array}{llll}(2.88460) & (2.94559) & (3.19232) & (3.04301)\end{array}$

$\begin{array}{llll}-1.27151 & -0.58288 & -1.39425 & -1.80144\end{array}$

$\begin{array}{llll}(-0.64100) & (-0.29991) & (-0.57857) & (-0.74356)\end{array}$

$\begin{array}{llll}-2.40575 & -1.72324 & -3.22434 & -2.32152\end{array}$

$(-1.18623) \quad(-0.86225) \quad(-1.28467) \quad(-0.92646)$

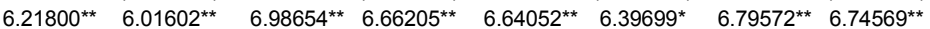

$\begin{array}{llllllll}(3.05019) & (2.94156) & (3.50062) & (3.32608) & (2.66888) & (2.54572) & (2.74522) & (2.69269)\end{array}$

$\begin{array}{lllll}-4.59404 & -7.24119 & -9.59668+ & -9.38277 & -5.84219\end{array}$

$\begin{array}{llll}(-0.99097) & (-1.57285) & (-1.86805) & (-1.63303)\end{array}$

$\begin{array}{llll}2.51271 & 1.61861 & 0.26254 & 2.70550\end{array}$

$\begin{array}{llll}(0.53718) & (0.34911) & (0.04512) & (0.46993)\end{array}$

$-8.51273+-8.57277+-10.66764^{*}-10.64498^{*}-13.48010^{*}-14.44804^{*}-11.69286^{*}-11.75603^{*}$

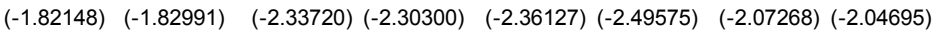

$-1.17267^{* *}-1.11343^{\star *} 2.58312+3.37758^{*}$

$(-3.18444)(-2.95272) \quad(1.93330)(2.45316)$

$-0.49274^{* *}-0.50139^{* *}-10.72853^{* *}-11.52922^{* *}$

$(-4.07162)(-4.06539)(-12.45871)(-13.00250)$

$1.48192^{\star *} 1.44482^{\star *} 5.47431^{\star *} 5.92465^{\star *}$

$\begin{array}{llll}(3.99269) & (3.79403) & (5.98727) & (6.39943)\end{array}$

$2.01282^{\star *} 2.04992^{\star *}$

(7.03600) (7.10742)

$-7.32082^{* *}-7.51679^{\star *} \quad-7.66670^{* *}-7.16202^{* *}-7.46180^{* *}-7.23795^{*} \quad-9.63729^{\star *}-9.91900^{* *}$

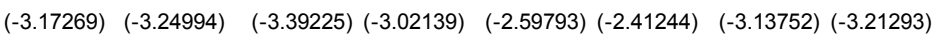

$4.35506 \quad 4.28510$

(1.64034) (1.60828)

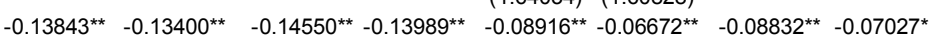

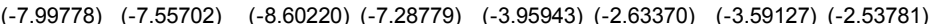

$\begin{array}{lll}0.05003 & -0.01442 & -0.03177\end{array}$

$(1.28044) \quad(-0.30091) \quad(-0.65299)$

$-0.08428^{*}-0.07321+-0.07143 \quad-0.04912$

$\begin{array}{lll}(-1.98659) & (-1.81907)(-1.39415) & (-0.95505)\end{array}$

$0.05649 \quad 0.01600 \quad 0.02784$

$\begin{array}{lll}(1.53120) & (0.34783) & (0.60324)\end{array}$

$0.01040 \quad 0.01531-0.02535+-0.01342$

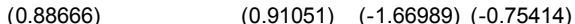

$0.00582 \quad-0.00421 \quad-0.01055$

(0.64559) (-0.34396) $\quad(-0.81070)$

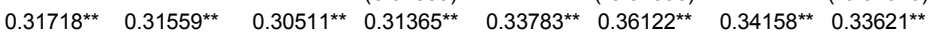

$\begin{array}{llllll}(15.79638) & (15.69133) & (15.32958)(15.35912) & (12.72403)(13.17606) & (13.34289) & (13.03859)\end{array}$ $-0.03450+-0.03740^{*}-0.06064^{* *}-0.06017^{* *}$

$(-1.85966)(-1.99922) \quad(-3.27599)(-3.24402)$

$\begin{array}{llllllll}0.24095^{* *} & 0.24059^{* *} & 0.24787^{* *} & 0.25089^{* *} & 0.23918^{* *} & 0.24312^{* *} & 0.24289^{* *} & 0.24342^{* *}\end{array}$

$\begin{array}{llllll}(24.63298) & (24.55765) & \text { (25.41791) (25.19678) } & \text { (18.72731) (18.80103) } & \text { (20.06651) (19.96642) }\end{array}$

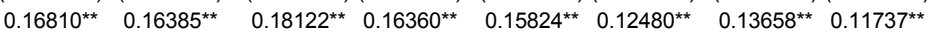

$\begin{array}{llllllll}(8.56167) & (8.20536) & (9.77742) & (6.98288) & (5.91650) & (3.86409) & (4.47360) & (3.61278)\end{array}$

$-0.00000-0.00000-0.00000^{* *}-0.00000^{* *}$

$(-1.60005)(-1.61160) \quad(-9.74065)(-9.85968)$

$0.00000^{* *} 0.00000^{* *}$

(9.79838) (9.92099)

$-0.00000^{* *}-0.00000^{* *}$

$(-8.65685)(-8.76460)$

$-7.00475^{* *}-7.13401^{* *}$

$(-9.72014)(-9.83868)$

$3.22749^{* *} \quad 3.29390^{* *} \quad 5.48352^{* *} 5.36428^{* *} \quad 11.15815^{* *} \quad 9.31214^{*} \quad 20.85738^{* *} 21.35429^{* *}$ $\begin{array}{lllllll}(12.76533) & (12.84791) & (8.74175) & (8.34092) & \text { (2.83386) } & \text { (2.27086) } & \text { (11.57424) (11.70371) }\end{array}$

\begin{tabular}{rrrrrrrr}
3,588 & 3,588 & 3,588 & 3,464 & 2,345 & 2,319 & 2,306 & 2,306 \\
0.24513 & 0.24593 & 0.25281 & 0.26177 & 0.26879 & 0.27462 & 0.25192 & 0.25404 \\
161 & 161 & & & 123 & 123 & 123 & 123 \\
\hline
\end{tabular}


Annex II. Table 6. Regression Results: Change in Current Account Balance/GDP

\begin{tabular}{|c|c|c|c|c|c|c|c|c|}
\hline & $(1)$ & $(2)$ & $(3)$ & $(4)$ & $(5)$ & $(6)$ & $(7)$ & $(8)$ \\
\hline & \multicolumn{2}{|c|}{ Static Fixed Effects } & \multicolumn{2}{|c|}{ Pooled OLS } & \multicolumn{2}{|c|}{ Fixed Effects } & \multicolumn{2}{|c|}{ Dynamic OLS } \\
\hline & Reduced & Augmented & Reduced & Augmented & Reduced & Augmented & Reduced & Augmented \\
\hline Banking crisis event, $\mathrm{t}-1$ & & & & & $\begin{array}{l}-1.03461+ \\
(-1.76242)\end{array}$ & $\begin{array}{l}-1.05990+ \\
(-1.79310)\end{array}$ & & \\
\hline Current account/GDP, $\mathrm{t}-1$ & & & $\begin{array}{r}-0.11468^{\star *} \\
(-13.10998)\end{array}$ & $\begin{array}{c}-0.11274^{\star *} \\
(-12.85126)\end{array}$ & $\begin{array}{c}-0.32409^{\star \star} \\
(-23.66452)\end{array}$ & $\begin{array}{c}-0.32384^{\star \star} \\
(-23.59970)\end{array}$ & & \\
\hline Investment/GDP, t-1 & & & $\begin{array}{l}-0.05781^{\star *} \\
(-5.81058)\end{array}$ & $\begin{array}{l}-0.05633^{\star *} \\
(-5.65819)\end{array}$ & $\begin{array}{r}-0.19752^{* *} \\
(-12.09149)\end{array}$ & $\begin{array}{c}-0.19710^{\star *} \\
(-12.04100)\end{array}$ & & \\
\hline Log private credit index, t-1 & & & $\begin{array}{l}-0.21455^{\star *} \\
(-2.81400)\end{array}$ & $\begin{array}{c}-0.17364^{*} \\
(-2.22998)\end{array}$ & $\begin{array}{c}-0.19869^{*} \\
(-2.29727)\end{array}$ & $\begin{array}{c}-0.19278^{*} \\
(-2.18724)\end{array}$ & & \\
\hline Log relative GDP index, $\mathrm{t}-1$ & & & $\begin{array}{l}-1.23323^{\star *} \\
(-3.56695)\end{array}$ & $\begin{array}{l}-1.27420^{\star \star} \\
(-3.67894)\end{array}$ & & & & \\
\hline Small country & & & $\begin{array}{l}-0.62420^{\star *} \\
(-3.21590)\end{array}$ & $\begin{array}{l}-0.56544^{\star \star} \\
(-2.87162)\end{array}$ & $\begin{array}{l}-1.54925^{\star} \\
(-2.08798)\end{array}$ & $\begin{array}{l}-1.52067^{*} \\
(-2.03834)\end{array}$ & & \\
\hline$\Delta$ Current account/GDP, $\mathrm{t}-1$ & & & $\begin{array}{l}-0.16070^{\star *} \\
(-9.69223)\end{array}$ & $\begin{array}{l}-0.16146^{\star *} \\
(-9.73529)\end{array}$ & $\begin{array}{l}-0.08225^{\star *} \\
(-4.93075)\end{array}$ & $\begin{array}{l}-0.08209^{\star \star} \\
(-4.91781)\end{array}$ & $\begin{array}{l}-0.08566^{\star \star} \\
(-4.45120)\end{array}$ & $\begin{array}{l}-0.08616^{\star \star} \\
(-4.47559)\end{array}$ \\
\hline$\Delta$ investment/GDP & $\begin{array}{r}-0.73321^{* *} \\
(-37.61160)\end{array}$ & $\begin{array}{c}-0.73334^{\star *} \\
(-37.60805)\end{array}$ & $\begin{array}{r}-0.69335^{\star *} \\
(-41.00344)\end{array}$ & $\begin{array}{r}-0.69167^{* *} \\
(-40.88800)\end{array}$ & $\begin{array}{r}-0.68045^{\star \star} \\
(-40.67959)\end{array}$ & $\begin{array}{c}-0.68005^{\star \star} \\
(-40.58162)\end{array}$ & $\begin{array}{r}-0.64905^{\star *} \\
(-35.45761)\end{array}$ & $\begin{array}{r}-0.64811^{\text {** }} \\
(-35.33527)\end{array}$ \\
\hline$\Delta$ investment/GDP, $\mathrm{t}-1$ & $\begin{array}{l}-0.05136^{* *} \\
(-2.71683)\end{array}$ & $\begin{array}{l}-0.05139^{\star *} \\
(-2.71716)\end{array}$ & $\begin{array}{l}-0.18131^{\text {** }} \\
(-9.62082)\end{array}$ & $\begin{array}{l}-0.17990^{* *} \\
(-9.54745)\end{array}$ & $\begin{array}{l}-0.11378^{\star *} \\
(-5.97139)\end{array}$ & $\begin{array}{l}-0.11362^{* *} \\
(-5.96048)\end{array}$ & $\begin{array}{l}-0.14757^{\star *} \\
(-6.73914)\end{array}$ & $\begin{array}{l}-0.14738^{* \star} \\
(-6.72759)\end{array}$ \\
\hline$\Delta$ Investment/GDP, $\mathrm{t}-2$ & & & & & & & $\begin{array}{l}-0.03003+ \\
(-1.72715)\end{array}$ & $\begin{array}{l}-0.02988+ \\
(-1.71850)\end{array}$ \\
\hline$\Delta$ log exchange rate index & $\begin{array}{r}0.07622^{*} \\
(2.56650)\end{array}$ & $\begin{array}{r}0.07022^{*} \\
(2.25670)\end{array}$ & & $\begin{array}{r}0.02596 \\
(1.07543)\end{array}$ & & $\begin{array}{r}0.00832 \\
(0.33746)\end{array}$ & $\begin{array}{c}0.05843+ \\
(1.93430)\end{array}$ & $\begin{array}{r}0.05886+ \\
(1.93705)\end{array}$ \\
\hline$\Delta$ log exchange rate index, $\mathrm{t}-1$ & & $\begin{array}{r}0.03663 \\
(1.36079)\end{array}$ & & $\begin{array}{r}0.04201^{*} \\
(2.21078)\end{array}$ & $\begin{array}{c}0.03286+ \\
(1.91192)\end{array}$ & $\begin{array}{c}0.03346+ \\
(1.77218)\end{array}$ & $\begin{array}{r}0.03529 \\
(1.39810)\end{array}$ & $\begin{array}{r}0.04704+ \\
(1.67292)\end{array}$ \\
\hline$\Delta$ log exchange rate index, $\mathrm{t}-2$ & & $\begin{array}{r}-0.01575 \\
(-1.35981)\end{array}$ & $\begin{array}{l}-0.01687^{*} \\
(-2.02430)\end{array}$ & $\begin{array}{l}-0.02661^{\star *} \\
(-2.93608)\end{array}$ & $\begin{array}{l}-0.02339^{\star *} \\
(-2.62042)\end{array}$ & $\begin{array}{l}-0.02389^{* *} \\
(-2.64543)\end{array}$ & & $\begin{array}{r}-0.02039 \\
(-1.48018)\end{array}$ \\
\hline$\Delta$ log exchange rate index $x$ small country & $\begin{array}{l}0.11558+ \\
(1.92426)\end{array}$ & $\begin{array}{c}0.11921+ \\
(1.93865)\end{array}$ & $\begin{array}{l}0.11617^{\star *} \\
(2.64269)\end{array}$ & $\begin{array}{c}0.09606+ \\
(1.92177)\end{array}$ & $\begin{array}{c}0.07872+ \\
(1.78141)\end{array}$ & $\begin{array}{r}0.07238 \\
(1.44656)\end{array}$ & $\begin{array}{c}0.17792^{*} \\
(2.29297)\end{array}$ & $\begin{array}{r}0.17731^{*} \\
(2.22716)\end{array}$ \\
\hline$\Delta$ log exchange rate index $x$ small country, $\mathrm{t}-1$ & & $\begin{array}{r}-0.00852 \\
(-0.14953)\end{array}$ & & $\begin{array}{r}-0.00794 \\
(-0.17492)\end{array}$ & & $\begin{array}{r}-0.01058 \\
(-0.23366)\end{array}$ & & $\begin{array}{r}-0.02597 \\
(-0.38543)\end{array}$ \\
\hline$\Delta$ log exchange rate index $x$ small country, $t-2$ & $\begin{array}{l}-0.11050^{* *} \\
(-2.87997)\end{array}$ & $\begin{array}{l}-0.09752^{*} \\
(-2.41536)\end{array}$ & $\begin{array}{l}-0.08449^{* *} \\
(-2.60087)\end{array}$ & $\begin{array}{l}-0.07672^{*} \\
(-2.30309)\end{array}$ & $\begin{array}{l}-0.06998^{*} \\
(-2.13801)\end{array}$ & $\begin{array}{l}-0.06827^{*} \\
(-2.05782)\end{array}$ & $\begin{array}{l}-0.17481^{\text {** }} \\
(-3.32707)\end{array}$ & $\begin{array}{l}-0.15686^{\star \star} \\
(-2.89813)\end{array}$ \\
\hline$\Delta$ log private credit, $\mathrm{t}-1$ & & & & & & & $\begin{array}{c}-0.03177^{*} \\
(-2.01937)\end{array}$ & $\begin{array}{l}-0.03174^{*} \\
(-2.01718)\end{array}$ \\
\hline$\Delta$ log private credit, $\mathrm{t}-2$ & & & & & & & $\begin{array}{c}0.01248+ \\
(1.68129)\end{array}$ & $\begin{array}{r}0.01693^{*} \\
(2.09780)\end{array}$ \\
\hline$\Delta$ log real credit index, $2005=100$ & $\begin{array}{l}-0.04829^{* *} \\
(-3.80146)\end{array}$ & $\begin{array}{l}-0.04928^{\star *} \\
(-3.82608)\end{array}$ & $\begin{array}{l}-0.02461^{* *} \\
(-2.83701)\end{array}$ & $\begin{array}{l}-0.03168^{\star *} \\
(-3.51714)\end{array}$ & $\begin{array}{l}-0.02624^{\star *} \\
(-2.84476)\end{array}$ & $\begin{array}{l}-0.02637^{\star *} \\
(-2.85457)\end{array}$ & $\begin{array}{l}-0.05177^{* *} \\
(-3.04641)\end{array}$ & $\begin{array}{l}-0.05284^{\text {** }} \\
(-3.10516)\end{array}$ \\
\hline$\Delta$ log relative GDP, $\mathrm{t}-2$ & $\begin{array}{c}0.14086+ \\
(1.72190)\end{array}$ & $\begin{array}{c}0.13918+ \\
(1.69600)\end{array}$ & $\begin{array}{r}0.13023+ \\
(1.86565)\end{array}$ & $\begin{array}{r}0.13430+ \\
(1.92459)\end{array}$ & $\begin{array}{l}0.19625^{\star \star} \\
(2.73038)\end{array}$ & $\begin{array}{l}0.19583^{\star *} \\
(2.72325)\end{array}$ & & \\
\hline$\Delta$ Official dev. assistance/GDP & $\begin{array}{l}-0.00864^{\star *} \\
(-3.80668)\end{array}$ & $\begin{array}{l}-0.00675^{\star *} \\
(-2.62140)\end{array}$ & & & & & $\begin{array}{r}0.01245 \\
(0.82366)\end{array}$ & $\begin{array}{r}0.01451 \\
(0.95523)\end{array}$ \\
\hline Speed of adjustment & & & & & & & $\begin{array}{c}-0.30135^{\star *} \\
(-19.33890)\end{array}$ & $\begin{array}{r}-0.30080^{\star *} \\
(-19.29278)\end{array}$ \\
\hline Constant & $\begin{array}{r}0.14506 \\
(1.13624)\end{array}$ & $\begin{array}{r}0.13629 \\
(1.05910)\end{array}$ & $\begin{array}{l}7.88581^{\star *} \\
(4.68337)\end{array}$ & $\begin{array}{l}7.83918^{\star *} \\
(4.65161)\end{array}$ & $\begin{array}{l}5.02143^{\star *} \\
(8.86864)\end{array}$ & $\begin{array}{l}4.97591^{* *} \\
(8.62389)\end{array}$ & $\begin{array}{r}-3.93785^{\star \star} \\
(-15.77984)\end{array}$ & $\begin{array}{r}-3.93078^{\star \star} \\
(-15.74646)\end{array}$ \\
\hline Observations & 2,523 & 2,523 & 3,268 & 3,268 & 3,268 & 3,268 & 2,468 & 2,468 \\
\hline R-squared & 0.39384 & 0.3946 & 0.42652 & 0.428 & 0.49324 & 0.49327 & 0.50493 & 0.50541 \\
\hline Number of countries & 127 & 127 & & & 160 & 160 & 132 & 132 \\
\hline
\end{tabular}


Annex II. Table 7. Regression Results: CPI Inflation

\begin{tabular}{|c|c|c|c|c|c|c|c|c|}
\hline & -1 & -2 & \multirow{2}{*}{\multicolumn{2}{|c|}{$\begin{array}{ll}-3 & -4 \\
& \text { Pooled OLS }\end{array}$}} & \multirow{2}{*}{\multicolumn{2}{|c|}{$\begin{array}{cc}-5 & -6 \\
& \text { Fixed Effects }\end{array}$}} & \multirow{2}{*}{\multicolumn{2}{|c|}{$\begin{array}{lc}-7 & -8 \\
\text { Dynamic OLS }\end{array}$}} \\
\hline & \multicolumn{2}{|c|}{ Static Fixed Effects } & & & & & & \\
\hline & Reduced & Augmented & \multicolumn{2}{|c|}{ Reduced Augmented } & Reduced & Augmented & Reduced & Augmented \\
\hline Devaluation event & & & & & & & $\begin{array}{l}-1.51435+ \\
(-1.82872)\end{array}$ & $\begin{array}{r}-1.27192 \\
(-1.52898)\end{array}$ \\
\hline \multirow[t]{2}{*}{ Devaluation event, $\mathrm{t}-1$} & & & & & & & & 0.87563 \\
\hline & & & & & & & & -1.05223 \\
\hline \multirow[t]{2}{*}{ Devaluation event, $\mathrm{t}-2$} & & & & & & & & -1.03139 \\
\hline & & & & & & & & $(-1.26450)$ \\
\hline \multirow[t]{2}{*}{ Devaluation event $x$ small country } & & & & & & & $17.94979^{* *}$ & $17.87518^{\star \star}$ \\
\hline & & & & & & & -5.77633 & -5.77639 \\
\hline \multirow[t]{2}{*}{ Devaluation event, $\mathrm{t}-1 \mathrm{x}$ small country } & & & & & & & $24.78971^{* *}$ & $24.32400^{\star \star}$ \\
\hline & & & & & & & -7.65592 & -7.28492 \\
\hline \multirow[t]{2}{*}{ Devaluation event, $\mathrm{t}-2 \mathrm{x}$ small country } & & & & & & & $-11.61093^{\star *}$ & $-10.16681^{\star \star}$ \\
\hline & & & & & & & $(-4.00713)$ & $(-3.38129)$ \\
\hline \multirow[t]{2}{*}{ Log broad money, t-1 } & & & & & $1.96367^{* *}$ & $1.96318^{\star *}$ & & \\
\hline & & & & & -8.85395 & -8.8232 & & \\
\hline \multirow[t]{2}{*}{ Log CPI, t-1 } & & & & & $-4.04778^{* *}$ & $-4.04681^{* *}$ & & \\
\hline & & & & & $(-8.52029)$ & $(-8.49435)$ & & \\
\hline \multirow[t]{2}{*}{ Log U.S. CPI, t-1 } & & & $3.10027^{\star *}$ & $3.30328^{\star *}$ & & & & \\
\hline & & & -6.23364 & -4.3445 & & & & \\
\hline \multirow[t]{2}{*}{ Output gap } & $0.08961^{* *}$ & $0.08986^{\star *}$ & $0.04190^{*}$ & $0.05180^{*}$ & $0.04172^{\star}$ & $0.04172^{*}$ & $0.04107^{*}$ & $0.04984^{*}$ \\
\hline & -3.6324 & -3.64029 & -2.5548 & -2.05452 & -1.97412 & -1.97343 & -2.01793 & -2.43438 \\
\hline$\Delta$ log broad money & $0.04689^{\star \star}$ & $0.04779^{\star \star}$ & $0.04296^{\star \star}$ & $0.08394^{\star \star}$ & $0.05401^{\star \star}$ & $0.05400^{\star \star}$ & $0.04410^{* *}$ & $0.04296^{\star \star}$ \\
\hline & -4.25522 & -4.31609 & -4.76266 & -6.12489 & -5.62497 & -5.62137 & -4.81032 & -4.70282 \\
\hline$\Delta$ log broad money, $\mathrm{t}-1$ & $0.07633^{* *}$ & $0.07655^{\star *}$ & $0.05677^{* *}$ & $0.12933^{* *}$ & $0.05016^{* *}$ & $0.05013^{* *}$ & $0.05357^{* *}$ & $0.05136^{\star \star}$ \\
\hline & -6.84817 & -6.82505 & -6.18221 & -9.41558 & -5.20474 & -5.16745 & -5.66309 & -5.44464 \\
\hline$\Delta \log$ broad money, $\mathrm{t}-2$ & $0.05626^{\star *}$ & $0.05688^{\star *}$ & & & & & $0.01512+$ & $0.02025^{\star}$ \\
\hline & -5.73691 & -5.7824 & & & & & -1.80513 & -2.38089 \\
\hline$\Delta \log \mathrm{CPI}, \mathrm{t}-1$ & & & $0.54758^{* *}$ & & $0.40688^{* *}$ & $0.40691^{* *}$ & $0.43819^{* *}$ & $0.41037^{\star \star}$ \\
\hline & & & -30.6015 & & -19.61647 & -19.58355 & -23.14233 & -19.84074 \\
\hline$\Delta$ log exchange rate & $0.16028^{* *}$ & $0.15934^{\star *}$ & $0.18109^{\star *}$ & $0.03200^{*}$ & $0.15728^{\star *}$ & $0.15727^{\star *}$ & $0.17936^{* *}$ & $0.17158^{\star \star}$ \\
\hline & -14.75333 & -14.58625 & -19.57838 & -2.25146 & -16.57147 & -16.56311 & -19.09053 & -17.87203 \\
\hline$\Delta$ log exchange rate, $\mathrm{t}-1$ & $0.10863^{* *}$ & $0.11195^{\star \star}$ & $0.01733+$ & $0.20894^{\star *}$ & $0.02802^{\star *}$ & $0.02804^{\star *}$ & & $0.03007^{\star \star}$ \\
\hline & -11.29162 & -10.74803 & -1.76246 & -14.84371 & -2.90596 & -2.89763 & & -2.98762 \\
\hline$\Delta$ log exchange rate, $\mathrm{t}-2$ & $0.02887^{* *}$ & $0.02927^{* *}$ & $-0.02040^{*}$ & $0.18381^{* *}$ & $-0.01402+$ & $-0.01411+$ & $-0.01397+$ & -0.01229 \\
\hline & -3.26138 & -3.09252 & $(-2.51164)$ & -14.91726 & $(-1.75132)$ & $(-1.65028)$ & $(-1.68784)$ & $(-1.44114)$ \\
\hline$\Delta$ log exchange rate $x$ small country & $0.15533^{\star *}$ & $0.16490^{\star *}$ & $0.18383^{* *}$ & -0.01285 & $0.12572^{* \star}$ & $0.12576^{\star \star}$ & -0.04877 & -0.04313 \\
\hline & -5.28241 & -5.24794 & -6.99622 & $(-0.31753)$ & -4.67865 & -4.6717 & $(-1.49735)$ & $(-1.32896)$ \\
\hline$\Delta$ log exchange rate, $\mathrm{t}-1 \mathrm{x}$ small country & & -0.02101 & $-0.14543^{* *}$ & $0.21093^{\star *}$ & $-0.11577^{* *}$ & $-0.11601^{* *}$ & $-0.09131^{* *}$ & $-0.10952^{\star \star}$ \\
\hline & & $(-0.79801)$ & $(-6.97306)$ & -6.01715 & $(-5.48463)$ & $(-5.11357)$ & $(-4.05974)$ & $(-4.70281)$ \\
\hline$\Delta$ log exchange rate, $\mathrm{t}-2 \mathrm{x}$ small country & & -0.00137 & & $-0.06458^{*}$ & & 0.00059 & 0.02164 & 0.02333 \\
\hline & & $(-0.05691)$ & & $(-2.07910)$ & & -0.02917 & -1.08631 & -1.16839 \\
\hline$\Delta \log$ U.S. CPI & $1.09585^{* *}$ & $1.09315^{\star *}$ & $1.48349^{\star *}$ & $-0.43430^{* *}$ & $1.29520^{\star *}$ & $1.29528^{\star *}$ & $1.47909^{* *}$ & $1.46868^{\star \star}$ \\
\hline & -12.65832 & -12.60085 & -17.55668 & $(-3.35096)$ & -16.24893 & -16.2333 & -18.84505 & -18.7649 \\
\hline$\Delta \log$ U.S. CPI, t-1 & & & $-0.65505^{\star *}$ & $1.27515^{\star *}$ & $-0.46469^{* *}$ & $-0.46469^{* *}$ & $-0.50781^{* *}$ & $-0.43043^{\star \star}$ \\
\hline & & & $(-8.21562)$ & -10.84168 & $(-5.92362)$ & $(-5.92115)$ & $(-6.93224)$ & $(-5.52262)$ \\
\hline$\Delta \log$ U.S. CPI, t-2 & & & $0.11462+$ & 0.07515 & $0.12839^{*}$ & $0.12832^{*}$ & $0.21870^{* *}$ & $0.19499^{\star \star}$ \\
\hline & & & -1.81388 & -0.77219 & -2.1574 & -2.15368 & -3.65518 & -3.21635 \\
\hline Speed of adjustment & & & & & & & $-1.77335^{\star *}$ & $-1.80355^{\star \star}$ \\
\hline & & & & & & & $(-7.87866)$ & $(-8.04069)$ \\
\hline Constant & -0.35555 & -0.37136 & $-17.81590^{\star *}$ & $-17.40485^{\star \star}$ & $9.72084^{* *}$ & $9.71864^{\star *}$ & $-20.07025^{\star *}$ & $-20.40768^{\star \star}$ \\
\hline & $(-1.32954)$ & $(-1.38469)$ & $(-6.36623)$ & $(-4.06456)$ & -5.82946 & -5.81982 & $(-8.04188)$ & $(-8.20724)$ \\
\hline Observations & 1,315 & 1,315 & 1,327 & 1,327 & 1,327 & 1,327 & 1,315 & 1,315 \\
\hline R-squared & 0.49152 & 0.49184 & 0.76592 & 0.59524 & 0.64158 & 0.64158 & 0.66219 & 0.6662 \\
\hline Number of countries & 78 & 78 & & & 78 & 78 & 78 & 78 \\
\hline
\end{tabular}

Note: t-statistics in parenthesis. ${ }^{* *},{ }^{*},+$ denote significance at the 1,5 , and 10 percent levels, respectively. 


\section{REFERENCES}

Cooper, R., 1971, “Currency Devaluation in Developing Countries”, Essays in International Finance No. 86, (Princeton, NJ: Princeton University).

Diaz-Alejandro, C., 1963, "A Note on the Impact of Devaluation and the Redistributive Effect, “Journal of Political Economy, Vol. 71, (December 1963), pp. 577-80.

Edwards, Sebastian, 1986, “Are Devaluations Contractionary?”, Review of Economics And Statistics, vol. 68, no. 3, pp. 501-508.

Gupta, P., D. Mishra and R. Sahay, 2003, "Output Response to Currency Crises”, IMF Working Paper WP/03/230 (Washington: International Monetary Fund).

Gylfason, T. and Schmid, M., 1983. "Does Devaluation Cause Stagflation?" Canadian Journal of Economics, Canadian Economics Association, vol. 16(4), pages 641-54, November.

Gylfason, T. and Risager, O., 1984, "Does Devaluation Improve the Current Account?”, European Economic Review, vol. 25, no. 1, pp. 37-64.

Hershman, A., 1949, "Devaluation and the Trade Balance: A Note", Review of Economics and Statistics, vol. 31, pp. 50-53.

International Monetary Fund, 2013, "Macroeconomic Issues in Small States and Implications for Fund Engagement," at www.imf.org/external/np/pp/eng/2013/022013.pdf.

International Monetary Fund, 2015 "Macroeconomic Developments and Selected Issues in Small Developing States” at http://www.imf.org/external/np/pp/eng/2015/030915.pdf.

Krugman, P. and Taylor, L. 1978, “Contractionary Effects of Devaluation”, Journal of International Economics vol. 8, no. 3, pp. 445-456.

Krugman, P., 1999, "Balance Sheets, the Transfer Problem, and Financial Crisis", in P. Isard, A. Razin, and A. Rose, eds., International Finance and Financial Crises, (Boston: Kluwer Academic).

Kumhof, Michael; Laxton, Douglas; Muir, Dirk; and Mursula, Susanna, 2010, "The Global Integrated Monetary and Fiscal Model (GIMF): Theoretical Structure," IMF Working Paper 1034 (Washington: International Monetary Fund).

Laeven, Luc, and Fabian Valencia, 2008, "Systemic Banking Crises: A New Database," IMF Working Paper 08/244.

Larrain F. and Sachs J. 1986, Contractionary Devaluation and Dynamic Adjustment of Exports and Wages, 1986, NBER Working paper No. 2078 
Lizondo S. and Montiel, J. "Contractionary Devaluation in Developing Countries: An Analytical Overview”, Staff Papers - International Monetary Fund, Vol. 36, No. 1 (Mar., 1989), pp. 182-227

Magendzo, I., (2002) Are Devaluations Really Contractionary?, Central Bank of Chile Working paper, No. 182.

Milesi-Ferretti, Gian Maria, and Assaf Razin, 1998, "Current Account Reversals and Currency Crises: Empirical Regularities,” NBER Working Paper No. 6620 (Cambridge, Massachusetts: National Bureau of Economic Research).

Miskin, Frederick (1999), “Global Financial Instability: Framework, Events, Issues,” Journal of Economic Perspectives, Vol 13, No 4, pp. 3-20.

Muir, Dirk, 2013, “The Global Integrated Monetary and Fiscal Model (GIMF) Users' Manual," IMF (Washington: International Monetary Fund).

Tovar, C., 2005, "The Mechanics of Devaluations and the Output Response in a DSGE Model: How Relevant Is the Balance Sheet Effect?", BIS Working Paper No. 192 (Basel: Bank for International Settlements). 